\title{
Abnormal Metabolism in the Progression of Nonalcoholic Fatty Liver Disease to Hepatocellular Carcinoma: Mechanistic Insights to Chemoprevention
}

\author{
Danny Orabi ${ }^{1,2,3,4,5}$, Nathan A. Berger $4,6,7,8$ and J. Mark Brown 1,2,3,4,* \\ 1 Department of Cardiovascular and Metabolic Sciences, Lerner Research Institute of the Cleveland Clinic, \\ Cleveland, OH 44106, USA; orabid@ccf.org \\ 2 Center for Microbiome and Human Health, Lerner Research Institute of the Cleveland Clinic, \\ Cleveland, $\mathrm{OH} 44106$, USA \\ 3 Department of Molecular Medicine, Cleveland Clinic Lerner College of Medicine of Case Western Reserve \\ University, Cleveland, OH 44195, USA \\ 4 Case Comprehensive Cancer Center, Cleveland, OH 44106, USA; nab@case.edu \\ 5 Department of General Surgery, Cleveland Clinic, Cleveland, OH 44195, USA \\ 6 Department of Medicine, Case Western Reserve University School of Medicine, Cleveland, OH 44106, USA \\ 7 Department of Biochemistry, Case Western Reserve University School of Medicine, \\ Cleveland, $\mathrm{OH} 44106$, USA \\ 8 Department of Genetics and Genome Sciences, Case Western Reserve University School of Medicine, \\ Cleveland, OH 44106, USA \\ * Correspondence: brownm5@ccf.org; Tel.: +1-216-444-8340; Fax: +1-216-444-9404
}

Citation: Orabi, D.; Berger, N.A.; Brown, J.M. Abnormal Metabolism in the Progression of Nonalcoholic Fatty Liver Disease to Hepatocellular Carcinoma: Mechanistic Insights to Chemoprevention. Cancers 2021, 13, 3473. https://doi.org/10.3390/ cancers 13143473

Academic Editor: Luca Miele

Received: 3 June 2021

Accepted: 2 July 2021

Published: 11 July 2021

Publisher's Note: MDPI stays neutral with regard to jurisdictional claims in published maps and institutional affiliations.

Copyright: (c) 2021 by the authors. Licensee MDPI, Basel, Switzerland. This article is an open access article distributed under the terms and conditions of the Creative Commons Attribution (CC BY) license (https:/ / creativecommons.org/licenses/by/ $4.0 /)$.
Simple Summary: Nonalcoholic fatty liver disease (NAFLD) is a disorder of excess lipid accumulation within the liver. Rates of NAFLD have rapidly increased with the sudden rise in obesity and metabolic syndrome. NAFLD may lead to liver inflammation, fibrosis, and dysfunction, and in select cases, the development of liver cancer in the form of hepatocellular carcinoma (HCC). NAFLD is established as a leading cause of liver cancer, and its contribution is expected to grow. Abnormal hepatic lipid metabolism has been repeatedly associated with the progression of NAFLD to primary liver cancer. The current treatment of NAFLD is focused primarily on reducing liver inflammation and fibrosis. Using therapies that additionally target metabolic or lipid signaling pathways that are responsible for tumor development may work to reduce the risk of liver cancer in these patients.

Abstract: Nonalcoholic fatty liver disease (NAFLD) is on the rise and becoming a major contributor to the development of hepatocellular carcinoma (HCC). Reasons for this include the rise in obesity and metabolic syndrome in contrast to the marked advances in prevention and treatment strategies of viral HCC. These shifts are expected to rapidly propel this trend even further in the coming decades, with NAFLD on course to become the leading etiology of end-stage liver disease and HCC. No Food and Drug Administration (FDA)-approved medications are currently available for the treatment of NAFLD, and advances are desperately needed. Numerous medications with varying mechanisms of action targeting liver steatosis and fibrosis are being investigated including peroxisome proliferatoractivated receptor (PPAR) agonists and farnesoid X receptor (FXR) agonists. Additionally, drugs targeting components of metabolic syndrome, such as antihyperglycemics, have been found to affect NAFLD progression and are now being considered in the treatment of these patients. As NAFLD drug discovery continues, special attention should be given to their relationship to HCC. Several mechanisms in the pathogenesis of NAFLD have been implicated in hepatocarcinogenesis, and therapies aimed at NAFLD may additionally harbor independent antitumorigenic potential. This approach may provide novel prevention and treatment strategies.

Keywords: nonalcoholic fatty liver disease; nonalcoholic steatohepatitis; hepatocellular carcinoma; PPAR; bile acids; gut microbiome; autophagy 


\section{Introduction}

In the United States, primary liver cancer ranks fifth in cancer-related mortality [1], with hepatocellular carcinoma (HCC) comprising the majority of these tumors [2]. Nonalcoholic fatty liver disease (NAFLD) has recently emerged as a leading etiology [3], and some predict NAFLD will become the predominant cause of HCC in the next decade. This is in part due to advancement of vaccination programs and direct-acting antiviral therapies contributing to a decrease in chronic viral hepatitis cases, coupled with the continuing rise in obesity in developing nations [4,5]. While obesity is associated with a striking $40 \%$ of all cancers in the United States [6], the contribution of obesity and aberrant metabolism to hepatic malignancies is particularly important because of the central role that the liver plays in the metabolism of lipids and other nutrients. Several metabolic pathways contributing to the pathogenesis of NAFLD have been implicated in HCC development and progression, which may serve as novel therapeutic targets for prevention and treatment.

The American Association for the Study of Liver Diseases (AASLD) defines NAFLD as greater than five-percent liver steatosis in the absence of secondary causes such as alcohol or medications [7]. This may be further classified as liver steatosis in the absence or presence of liver inflammation and designated as nonalcoholic fatty liver (NAFL) or the more advanced manifestation of nonalcoholic steatohepatitis (NASH), respectively. The chronic inflammation produced by NASH may promote hepatic collagen deposition and fibrosis [8]. If severe enough, this leads to cirrhosis and critical liver dysfunction (i.e., end-stage liver disease). When HCC formation occurs in a patient with a history or histological pattern of NAFLD in the absence of viral, alcoholic, or other liver disease history, the etiology of HCC is presumed to be from NAFLD and will be referred to as NAFLD-related HCC in this text.

There are currently no Food and Drug Administration (FDA)-approved medications for the treatment of NAFLD. Additionally, while rates of NAFLD-related HCC are on the rise [3-5], no medications are currently recommended for the treatment of NAFLD as a primary preventive approach against HCC. Rather, the current efforts aimed at NAFLD-related HCC are focused on tools that improve screening, enable early detection, and inform timely effective intervention $[7,9]$. The treatment of NAFLD-related HCC is not distinguished from non-NAFLD cases despite a distinct pathogenesis and genetic landscape [10,11]. Systemic therapies for HCC have evolved from conventional cytotoxic chemotherapy to multikinase and checkpoint inhibitors, but 5-year survival still remains below $20 \%$ and improved prevention strategies are necessary [1]. Adopting an approach focused on reducing HCC development in NAFLD patients through the modulation of key metabolic pathways responsible for tumor development should provide valuable chemoprevention.

The association between aberrant metabolism and liver disease has traditionally been known as NAFLD. However, the widespread prevalence of metabolic dysfunction and the limitations imposed by the current definition of NAFLD have led an international consensus panel to propose a revised classification named metabolic-associated fatty liver disease (MAFLD) [12]. This revised classification advocates for diagnosis based primarily on the presence of metabolic dysfunction rather than the absence of secondary causes of liver disease, thereby making the diagnosis one of inclusion rather than exclusion. This revision is significant because it recognizes the often-present metabolic dysfunction that exacerbates liver pathology in chronic liver disease of various etiology, especially alcoholic liver disease. Emphasis on these metabolically focused pathogenic mechanisms will help to better understand disease progression and guide treatment. Since NAFLD is the traditionally designated form of disease, its definition will be used herein. However, we recognize that MAFLD will likely become the new designation given its more accurate and comprehensive approach. 


\section{Epidemiology and Predictions}

\subsection{NAFLD}

A recent meta-analysis by Younossi et al. that limited inclusion criteria to studies in which diagnosis was based on imaging reported a $25 \%$ prevalence of NAFLD in the United States [13]. While rates showed significant regional variation, a similar $25 \%$ prevalence was found globally. The prevalence of NASH among American NAFLD patients with or without an indication for liver biopsy was estimated to be $60 \%$ and $30 \%$, respectively. Highest rates of NAFLD are seen in Hispanics followed by Americans of European then African descent [14]. Initially, gender differences in NAFLD were unclear, with some reporting an increased prevalence among females [14], though recent data actually suggest a higher prevalence and severity among men compared to premenopausal women, with estrogen conferring a protective effect [15]. While studies may vary in reported prevalence of NAFLD due to differences in study populations and diagnostic criteria, there is little debate that rates are rising both in the United States and worldwide [13,14,16-18]. Cryptogenic cirrhosis is now being recognized as a form of "burnt-out NASH", which describes the loss of steatosis in NASH patients with advanced fibrosis, and may account for the historical underestimation of disease burden $[4,14,19]$.

\subsection{NAFLD-Related HCC}

A review detailing the epidemiology of NAFLD-related HCC by Kogiso et al. is included in this special edition of MDPI Cancers [20]. Here, we will briefly summarize key epidemiologic concepts and predictions relevant to this review.

Leading etiologies of HCC in the United States and worldwide are chronic infection with hepatitis B or C virus, chronic excessive alcohol consumption, and NAFLD, with the genetic (e.g., alpha 1 antitrypsin, hemochromatosis) and environmental (e.g., aflatoxin) causes being less frequent [3-5]. Current estimates report NAFLD-related HCC to constitute $10-20 \%$ of HCC in the United States [3,4,21,22], though variability in definitions, diagnostic criteria, and patient populations confound these epidemiologic studies. Older age, male sex, Hispanic ethnicity, and the presence of cirrhosis are risk factors for HCC development in NAFLD patients [23]. NALFD is the fastest growing indication for HCC-related liver transplantation in the United States, and currently ranks second only to hepatitis C infection [24]. While the risk estimate of HCC development in NAFLD patients is approximately 10 -fold lower than that of hepatitis B or C infection, the overwhelming prevalence of NAFLD has propelled it to become a leading cause [4,22]. Strong advancements in hepatitis $B$ and $C$ virus prevention strategies and treatment will continue to lessen their attributable HCC burden [4,5].

Cryptogenic cirrhosis, representing "burnt-out NASH", has led studies to attribute HCC etiology in such cases to NAFLD $[4,14,19]$. A variation of this requires HCC patients with cryptogenic cirrhosis to additionally have at least one component of metabolic syndrome (obesity, diabetes, dyslipidemia, or hypertension). The rationale for this specification is that metabolic syndrome increases the likelihood of concurrent NAFLD and that these metabolic derangements independently confer higher risk of HCC development. The contributions of individual components of metabolic syndrome on HCC development and progression will be highlighted in the next section.

\section{HCC and Metabolic Syndrome}

\subsection{Metabolic Syndrome}

Metabolic syndrome, or "syndrome X," describes the constellation of obesity, hyperglycemia/insulin resistance, dyslipidemia, and hypertension $[25,26]$. It has now become accepted that NAFLD is both a cause and consequence of metabolic syndrome through the interrelationship of liver metabolism and systemic metabolic homeostasis $[27,28]$. There is a tendency to view metabolic syndrome and NAFLD as a separate, irrelevant entity in the context of non-NAFLD-related HCC. However, metabolic derangements and NAFLD confer higher HCC risk and poorer prognosis in patients with chronic liver disease of 
various etiologies and will be discussed below. We propose HCC as the culmination of a complex multifactorial process with metabolic syndrome and NAFLD playing key roles (Figure 1). An emphasis should be placed on improving overall metabolic health in all patients with chronic liver disease, especially those at high risk for HCC development.

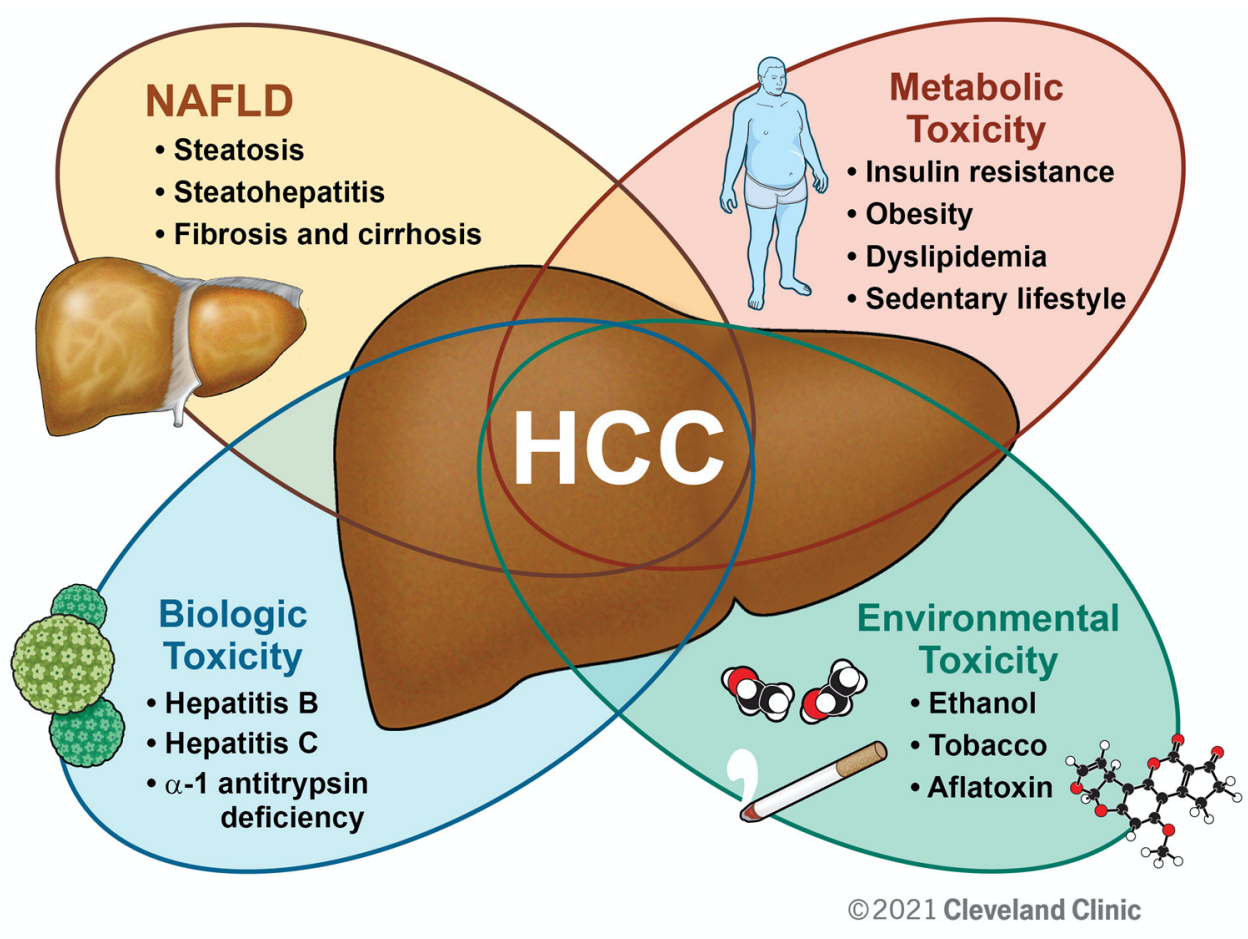

Figure 1. The Role of NAFLD and Metabolic Syndrome in HCC. Illustrated is a working model by which diverse factors may compound one another to promote HCC. While individual patients will have certain "drivers" of disease, emphasis should be placed on improving metabolic parameters as a primary preventive strategy against HCC from chronic liver disease of various etiologies.

\subsection{Obesity and Dyslipidemia}

In addition to lipid storage, adipose tissue functions as an endocrine organ modulating hormones and cytokines to affect insulin resistance, endothelial dysfunction, systemic inflammation, and much more $[29,30]$. Rising rates of NAFLD have been accompanied by the rise in obesity over the last half century [31,32]. NAFLD risk markedly increases with higher body mass index (BMI) in a dose-dependent manner, with obesity (BMI $>30 \mathrm{~kg} / \mathrm{m}^{2}$ ) conferring a 3- to 7-fold higher risk [33,34]. Obesity additionally serves as an independent risk factor for HCC overall [35-37], as well as in hepatitis C and alcoholic cirrhosis [38-40], but does not appear to do so in chronic hepatitis B infection [38,41]. The effect of obesity on prognosis and survival is confounded by differences in stage at diagnosis, treatment modalities, and gender differences, as well as by overall patient decompensation secondary to advanced tumor burden and treatment effects [42]. The use of obesogenic high-fat diets in animal models of HCC supports its pro-inflammatory and tumorigenic effect $[43,44]$. In addition to fostering HCC development indirectly by promoting NAFLD progression, obesity may independently promote HCC development through adipokine-mediated immunomodulation and carcinogenesis [45].

Dyslipidemia and notably hypertriglyceridemia are key components of metabolic syndrome. The relationship between dyslipidemia, NAFLD, and HCC is obscured by the liver's role in lipid homeostasis. While elevated cholesterol and triglyceride levels are clear risk factors for NAFLD $[46,47]$, the liver dysfunction frequently seen after HCC development is associated with decreased serum lipid levels $[48,49]$. 


\subsection{Insulin Resistance}

Insulin resistance denotes the impaired ability of target tissues to respond to insulin signaling and effectively maintain systemic glucose homeostasis [50]. This leads to hyperglycemia, initially with hyper- followed by hypoinsulinemia from pancreatic beta-cell failure. This directly and indirectly affects hepatic lipid metabolism to promote NAFLD $[28,50,51]$. Epidemiologic studies support an independent role for diabetes in the development of HCC, regardless of etiology [36,52-54]. It should be noted, however, that liver disease may promote the development of diabetes, thereby confounding these population studies, and data should be interpreted with caution. Nonetheless, the tumorigenic role of insulin resistance using in vitro and animal models strongly supports causation. For example, insulin resistance has been shown to promote hepatic steatosis via insulin receptor substrate-1 (IRS1) activation of sterol regulatory element-binding protein-1c (SREBP1c), the major regulator of hepatic fatty acid synthesis [51,55]. Similarly, IRS1 and SREBP1c were found to promote HCC development and progression [56,57].

Metabolic syndrome is intimately related to HCC development and progression in chronic liver disease of various etiology. The pathogenic mechanisms conferring this increased risk are being investigated with an emphasis on their role in the development of NAFLD-related HCC. However, mechanisms found to be responsible may additionally play pathogenic roles in HCC of non-NAFLD etiology. Metabolic parameters should be optimized in NAFLD and non-NAFLD chronic liver disease patients with or without HCC to mitigate the detrimental, tumorigenic effect of metabolic syndrome.

\section{Clinical Approach to NAFLD and NAFLD-Related HCC}

\subsection{Current Diagnostic and Treatment Strategies of NALFD}

The latest AASLD Practice Guidance recommendations will be used to summarize diagnostic and treatment approaches for NAFLD [7]. Due to the lack of evidence, no current screening practices are recommended and NAFLD is most often incidentally diagnosed. Differentiating NAFL from NASH has clinical significance as the latter indicates substantially higher morbidity $[13,58,59]$. While liver biopsy is the gold standard to diagnose NASH and its severity, it is invasive and costly. There have been advances in non-invasive diagnostic methods, in particular validated predictive score models, serum markers representative of liver fibrosis, and advanced non-invasive imaging techniques [60].

Early treatment of NAFLD aims at lifestyle modification and avoidance of exacerbating factors, for which the literature has provided strong support. Weight loss, exercise, and avoidance of heavy alcohol use have repeatedly been shown to significantly improve markers of disease, even reversing early fibrosis in some cases [61-65]. Pharmacologic therapy in NAFLD is reserved for patients with NASH and often limited to those with advanced fibrosis. Bariatric surgery is considered in NAFLD patients unable to meet weight loss goals and has been shown to impressively reverse NAFLD and decrease the risk of HCC [9,66], further supporting preventative strategies that focus on managing the metabolic disturbances associated with obesity. The major liver-directed drug therapies in use today include pioglitazone, liraglutide, and vitamin E, and these will be discussed in detail in the following sections. Obeticholic acid, a bile acid analogue and farnesoid $X$ receptor (FXR) agonist, is in an ongoing phase 3 clinical trial and elafibranor, a dual peroxisome proliferator-activated receptor (PPAR) $\alpha / \delta$ agonist, recently completed its phase 3 trial and will also be discussed in the following sections. Less prevalent medications used specifically for their liver-directed effects are statins and aspirin [67]. Metformin and omega-3 fatty acids are considered though do not appear to provide benefit $[68,69]$.

\subsection{Current Prevention and Treatment Strategies of NAFLD-Related HCC}

The prevention strategy of NAFLD-related HCC parallels the treatment of NAFLD. This stems from the notion that HCC develops more commonly in advanced liver disease, i.e., late-stage fibrosis or cirrhosis, and HCC screening is currently only recommended for NAFLD patients with cirrhosis $[7,70]$. However, the approach is problematic as NAFLD- 
related HCC often develops in the absence of cirrhosis [4,23,71,72], though this is unclear and may vary by population $[20,70,73]$. Nonetheless, patients with NAFLD-related HCC are often diagnosed at a later stage compared to their viral and alcoholic counterparts and advances in screening and prevention are needed [3,72,74].

The treatment approach for NAFLD-related HCC is not distinguished from HCC of different etiology [70]. Curative approaches involve surgical resection or liver transplant, though advanced stage disease at presentation often eliminates these options. Adjuvant treatments include ablation, radio- and chemoembolization, radiation therapy, and systemic therapy. Sorafenib and other related multikinase inhibitors in addition to nivolumab, a checkpoint inhibitor, have emerged as the leading systemic therapies in HCC. Conventional cytotoxic chemotherapy is infrequently used.

\section{Therapeutic Targets in NAFLD and NAFLD-Related HCC}

Pathogenic mechanisms responsible for NAFLD progression may also independently promote HCC. Therefore, therapeutic strategies that primarily prevent NAFLD progression may have strong potential to likewise improve HCC outcomes. Numerous clinical trials have investigated the safety and efficacy of prospective NAFLD therapies with mixed results. Here, we briefly review current molecular targets that have been explored for NAFLD, and discuss how they may hold promise in NAFLD-related HCC.

\subsection{PPARs}

PPARs are nuclear receptors that play intimate roles in glucose and lipid metabolism [75]. Three isoforms exist, each varying in tissue distribution and function. The most wellknown is PPAR $\gamma$, the target of the thiazolidinedione (TZD) class of medications that are in widespread use today. PPAR $\gamma$ is primarily expressed in adipocytes and promotes adipocyte differentiation and lipogenesis. PPAR $\alpha$ is highly expressed in liver and functions in fatty acid uptake and beta-oxidation. PPAR $\beta / \delta$, also known as PPAR $\beta$ or PPAR $\delta$, plays a prominent role in intestinal, liver, and skeletal muscle lipid metabolism, affecting mitochondrial function and fatty acid oxidation. All three isoforms have been established to play a role in NAFLD development and progression $[75,76]$, and have additionally been implicated in HCC.

\subsubsection{Thiazolidinediones and PPAR $\gamma$}

PPAR $\gamma$ is highly expressed in adipocytes, where it plays a critical role in the transcriptional control of adipocyte differentiation and triglyceride metabolism [75]. Liganddependent activation of PPAR $\gamma$ increases lipogenesis and decreases lipolysis, promoting the accumulation of cellular lipids such as triglycerides [75]. Thiazolidinediones (TZDs) are the predominant class of PPAR $\gamma$ agonists that have been used clinically, and pioglitazone and rosiglitazone are currently available in the United States. TZDs are most known for their insulin-sensitizing ability and their leading role in the treatment of hyperglycemia, though are currently second- or third-line antidiabetic agents due to their adverse effects [77]. TZDs exert their antihyperglycemic effects via PPARy-mediated adipocyte proliferation and lipogenesis to reduce circulating free fatty acids, as well as via modulation of adipokine levels and relevant cytokines $[75,78,79]$. These effects additionally reduce NAFLD progression $[78,79]$. Multiple clinical trials have demonstrated reduced steatosis, inflammation, and fibrosis in NAFLD patients with pioglitazone therapy $[78,80]$. Currently, AASLD treatment guidelines recommend pioglitazone in NASH patients with or without concomitant diabetes, with careful consideration of patient risk versus benefit [7].

The association between prior TZD treatment and lower HCC incidence is well described [52,81-86], with a prospective case-control study by Hassan et al. at MD Anderson Cancer Center in Houston, Texas demonstrating up to a 70\% risk reduction [52]. Pioglitazone has been shown to exhibit numerous direct antitumorigenic roles in a variety of cancers [87], especially hepatocellular carcinoma [88-90]. In a recent study by Li et al., pioglitazone improved fibrosis and HCC tumor burden in two rodent models of 
HCC [88]. Adiponectin-mediated 5'-adenosine monophosphate (AMP)-activated protein kinase (AMPK) activation with subsequent mitogen-activated protein kinase (MAPK) downregulation was implicated. Several other studies have shown direct antitumorigenic effects via PPAR $\gamma$ activation $[90,91]$. Interestingly, early literature suggest pioglitazone may also achieve direct antitumorigenic effects through PPAR $\gamma$-independent mechanisms [92,93], though more investigation is needed. In summary, population studies and preclinical models of disease provide evidence for the use of pioglitazone as chemoprevention of HCC. A limitation of population studies is their retrospective nature as well as heterogeneous cohorts with many non-NAFLD patients. A prospective randomized study is needed.

\subsubsection{Fibrates and PPAR $\alpha$}

In humans and rodents, PPAR $\alpha$ is predominantly expressed in the liver, where it plays a major role in hepatic and systemic lipid metabolism [94,95]. Early PPAR $\alpha$-activating drugs include the fibrates, notably fenofibrate, gemfibrozil, bezafibrate, and clofibrate. Rodent models have consistently demonstrated the role of PPAR $\alpha$ in fatty acid transport and beta-oxidation, leading to improvement in serum lipid profiles, hepatic steatosis, and insulin resistance [96-101]. Fibrates are currently used for the treatment of dyslipidemia, particularly hypertriglyceridemia. Large clinical trials demonstrated their ability to improve serum lipid profiles with relatively few adverse events [102,103], though side effects include transient hepatic transaminase elevations and myopathy [104-106]. The ability of $\operatorname{PPAR} \alpha$ activation to improve liver steatosis and steatohepatitis as well as insulin resistance in rodents led to a few small clinical studies to determine the effects of fibrates on NAFLD progression [107-111]. Some of these studies demonstrated improvement with fibrate therapy, though data were limited by low sample sizes, the use of combination therapy, and suboptimal methods of assessment. The excitement of PPAR $\alpha$ activation in the treatment of NAFLD subsided until recently with the emergence of selective PPAR $\alpha$ modulators (SPPARM $\alpha$ ), a class of compounds designed to more precisely and potently target PPAR $\alpha$ while minimizing side effects. Permafibrate (or K-877), a SPPARM $\alpha$, was shown to improve dyslipidemia over both placebo and fenofibrate administration in a phase 2 clinical trial [112]. Honda et al. demonstrated improvements in obesity, dyslipidemia, and histological markers of NAFLD in two rodent models of NASH using permafibrate treatment, with increased hepatic expression of acyl-CoA oxidase 1 (ACOX1) and uncoupling protein 3 (UCP3) [113]. Another preclinical rodent model of NASH demonstrated permafibrate's ability to reduce NASH progression via immune cell alterations [114]. Recent phase 2 and 3 trials demonstrate permafibrate's ability to treat dyslipidemia and also improve Homeostatic Model Assessment for Insulin Resistance (HOMA-IR) scores in diabetic patients with a low rate of adverse events [115,116]. A recent small study of 10 biopsy-proven NASH patients showed improvements with permafibrate therapy by non-invasive assessments of fibrosis (fibrosis- 4 index, aspartate aminotransferase-to-platelet ratio index), further supporting a potential role for PPAR $\alpha$ in the treatment of NAFLD [117].

Effects of PPAR $\alpha$ activation on HCC have been clouded by the marked interspecies differences in liver PPAR $\alpha$ gene expression and target gene modulation between humans and rodents [118]. It was found early on that PPAR $\alpha$ activators, fibrates and WY-14643, led to the formation of paraneoplastic foci and HCC in mice and rats after 50 weeks of administration $[119,120]$, though thorough subsequent investigation has found this does not translate to human studies [121-123]. PPAR $\alpha$ knockout mice were found to be more susceptible to diethylnitrosamine (DEN)-induced HCC with nodules demonstrating a higher proliferative index by Ki-67 staining and decreased levels of apoptosis through knockout-mediated activation of NF- $\mathrm{kB}$ signaling [124]. Several in vitro studies on cultured human hepatocytes have demonstrated a direct antitumorigenic role of fibrates mediated via changes in cyclin-dependent kinase (CDK) and cyclin levels as well as apoptotic protein levels along with radical oxygen species (ROS) formation, protein kinase B (AKT) signaling, and fatty acid synthase (FASN)-mediated lipid synthesis [125-128]. Some of these effects were found to be mediated via PPAR $\alpha$-independent mechanisms, suggesting 
differences observed between PPAR $\alpha$ activators may be attributed to drug-specific effects on non-PPAR $\alpha$ targets [125]. The use of human-based organoid culture models and nonrodent animal models of HCC may help elucidate the antitumorigenic potential of PPAR $\alpha$ activators. New more potent and selective drugs such as permafibrate, a SPPARM $\alpha$, may bring new treatment options to NAFLD and NAFLD-related HCC.

\subsubsection{PPAR $\delta$}

PPAR $\delta$ is the least characterized of the PPARs. PPAR $\delta$ is most highly expressed in intestinal and liver tissues [129-131], though its function in skeletal muscle has been the major focus [132-134]. Early studies demonstrated PPAR $\delta$ activation may improve the serum lipid profile, notably HDL and TGs, as well as insulin resistance and obesity [135-137]. Animal and human studies then found PPAR $\delta$ activation may also improve NAFLD $[75,76,135,138-143]$. Despite strong evidence for PPAR $\delta$ activation in the treatment of metabolic disorders, a major setback occurred after the PPAR $\delta$ agonist GW501506 was found to promote carcinogenesis, particularly colon cancer, in rodent models $[135,136,144]$. However, subsequent analyses and reviews have found PPAR $\delta$ activation may indeed harbor antitumorigenic properties, though a consensus has not been reached and further investigation is needed $[136,145]$. Interestingly, the activation of PPAR $\delta$ leads to hepatic accumulation of 16:0/18:1-phosphatidylcholine, a ligand of PPAR $\alpha$, which may confound studies utilizing rodent models of HCC as discussed above [146].

Elafibranor, or GFT505, is a dual PPAR $\alpha / \delta$ agonist that showed promise in early clinical trials, leading to improved serum lipid profiles and insulin resistance in dyslipidemic and prediabetic/diabetic patients, respectively $[147,148]$. These effects appeared to be mediated via hepatic PPAR signaling pathway activation rather than in skeletal muscle by gene expression analysis [148]. A mouse model of NASH also demonstrated elafibranor's positive effects on histological and serum markers of disease [149]. Afterwards, a larger randomized control trial in approximately 300 patients with NASH without cirrhosis was performed comparing two doses of elafibranor to placebo, with the primary endpoint of NASH resolution without fibrosis worsening [150]. While the predefined endpoint was not met when using an older definition of NASH, the use of a newer modified definition showed the higher-dose $(120 \mathrm{mg} /$ day) elafibranor-treated group was more likely to meet primary endpoint when compared to placebo. These patients additionally displayed improved serum lipid profiles, insulin sensitivity, and markers of systemic inflammation. Unfortunately, in another major setback, a recent phase 3 trial (NCT02704403) found 72 weeks of elafibranor (120 mg/day) treatment in NASH fibrosis patients did not meet primary or secondary endpoints, though was confounded by a high rate of improvement in the placebo group. With preclinical models continuing to show NASH improvement with elafibranor treatment $[151,152]$ as well as the suppression of HCC with PPAR $\delta$ activation $[153,154]$, the future of PPAR $\delta$-targeting therapies in the treatment of NAFLD and NAFLD-related HCC is possible.

\subsection{Bile Acids}

Primary bile acids are amphipathic molecules synthesized by hepatocytes from cholesterol [155]. They are conjugated and transported to bile canaliculi and subsequently the intestine where microbes may perform additional modifications, and then are either secreted in stool or, much more commonly, recycled back to the liver via the enterohepatic circulation [155]. Liver and plasma levels correlate with liver disease, but the composition of the bile acid pool is likely the biggest determinate of liver disease progression [155-157]. The relationship of bile acids to metabolic disorders, notably diabetes and NAFLD, has gained much interest in the past decade $[155,158]$. While bile acid accumulation in NAFLD may directly result in liver toxicity to promote cholestatic liver injury [159-161], specific bile acids also play major roles in cell signaling pathways. The most prominent example of the latter is the ability of the endogenous bile acid, chenodeoxycholic acid, to activate the major suppressor of hepatic bile acid synthesis, FXR [162]. Additionally, hepatic FXR 
activation promotes fatty acid beta oxidation and the suppression of lipogenesis, making it an especially attractive target in NAFLD $[155,158,163]$. Preclinical animal models found FXR activation improves NASH, insulin resistance, and the serum lipid profile [164-166]. In addition to their regulation of metabolic homeostasis, bile acids and their signaling pathways play important roles in carcinogenesis [167]. FXR knockout mice show increased levels of hepatic inflammation, notably through NF-KB activation [168], and display higher rates of HCC development [169-171]. The FXR agonist, GW4064, was found to suppress HCC in cell culture and a xenograft model through alterations in suppressor of cytokine signaling 3 (SOCS3), a major repressor of the signal transducer and activator of transcription 3 (STAT3) pathway [172]. FXR is downregulated in human HCC, and FXR knockout mice display liver transcriptome alterations consistent with human pathology [173].

The semi-synthetic bile acid analogue $6 \alpha$-ethyl-chenodeoxycholic acid, more commonly known as obeticholic acid, was developed and is the first FXR agonist to be used in humans. In a co-culture of hepatocytes and stellate cells, obeticholic acid reduced collagen deposition in a dose-dependent manner [174]. Rodent models of metabolic syndrome found obeticholic acid reduced liver steatosis and fibrosis and insulin resistance [152,175-177]. A phase 2 randomized control trial found obeticholic acid improved insulin resistance and decreased markers of liver inflammation and fibrosis in diabetic NAFLD patients [178]. A subsequent clinical trial of $283 \mathrm{NASH}$ patients in the United States demonstrated significantly improved liver histology with obeticholic acid compared to placebo (45\% vs. 21\%) [179]. Currently, a phase 3 multicenter randomized control trial (NCT02548351) of over 2000 NASH patients is underway, with an estimated completion date of October, 2022. An interim analysis of 931 patients showed an improvement in liver fibrosis scores with obeticholic acid treatment [180]. The most common adverse effect in these studies was pruritis, and increased rates of gallstone formation have been noted elsewhere [181]. Obeticholic acid has also been shown to have antitumorigenic properties against HCC, with a recent study showing alterations in interleukin-6 (IL-6)/STAT3 signaling [182]. While obeticholic acid is FDA approved for the treatment of primary biliary cholangitis, it was recently denied approval for the treatment of NAFLD and sent back to the pharmaceutical manufacturer (Intercept) with request for further efficacy data and safety analysis. Obeticholic acid or other FXR agonists (ex. Px-104) and bile acid analogues (ex. arachidyl amido cholanoic acid, i.e., Aramchol) have potential in the future of NAFLD treatment and NAFLD-related HCC chemoprevention.

Bile acid metabolism is complex, with numerous enzymes, signaling molecules, receptors, and transporters working in tandem. A notable illustration of this is the intestinal expression of FXR to sense bile acid concentrations, which upon activation leads to the increase in circulating fibroblast growth factor (FGF) 19 (FGF15 in mice) [183]. FGF15/19 binds to hepatocyte fibroblast growth factor receptor 4 (FGFR4) to inhibit cholesterol $7 \alpha$-hydroxylase A1 (CYP7A1), the rate-limiting enzyme in bile acid synthesis [183]. Additionally, while bile acids appear in far higher concentrations in the intestine and liver, they also play a direct role in systemic lipid and glucose metabolism and inflammation through various receptors $[155,158]$. The use of drugs and drug combinations targeting various bile acid-signaling molecules (FGF15/19), bile acid receptors (G protein-coupled bile acid receptor 1 (TGR5) and FGFR4), and bile acid transporters (apical sodium-dependent bile acid transporter (ASBT)) may provide novel targets in the approach to NAFLD and liver cancer $[155,158,163,184]$.

\subsection{GLP-1 Receptor Agonists}

Glucagon-like peptide-1 (GLP-1) receptor agonists (GLP-1RAs) such as liraglutide and exenatide are predominantly used for their antihyperglycemic properties. Upon feeding, the incretin GLP-1 is released by enteroendocrine L cells where it binds to GLP-1 receptors on pancreatic beta cells $[185,186]$. GLP-1 receptor binding promotes glucose-dependent pancreatic beta cell insulin release improving hyperglycemia as well as beta cell health to prevent diabetes progression. GLP-1 receptors may also be expressed on hepatocytes 
to modulate insulin signaling and lipid metabolism [187], though this has been debated and liver effects may be indirect $[188,189]$. However, a number of studies have reported their presence in human hepatocytes and have demonstrated direct effects of GLP-1RAs on hepatocytes and HCC cell lines in vitro [187,190-194]. Preclinical animal models have also demonstrated their positive effects on liver lipid metabolism and NAFLD [190,195-197]. Responsible mechanisms found include increased AMPK and PPAR $\alpha$ signaling along with modulation of SREBP1c and stearoyl-CoA desaturase-1 (SCD1) expression. A recent systematic review of 24 completed and 8 ongoing clinical trials found strong evidence for the use of GLP-1RAs in the treatment of NAFLD patients [198]. Shifting focus to HCC, preclinical animal models demonstrate the antitumorigenic properties of GLP-1RAs [194,199]. The corresponding antitumorigenic effect in vitro using cell culture models support a direct and independent mechanism [192-194]. Dipeptidyl peptidase-4 (DPP-4) inhibitors are antidiabetic agents that enhance circulating levels of incretins such as GLP-1. These agents are also under investigation in the treatment of NAFLD and have been found to harbor direct antihepatocarcinogenic properties in rodent models [200].

\subsection{ACC Inhibitors}

While increased hepatic de novo lipogenesis is a primary driver of the pathogenesis of NAFLD, it also plays a major role in HCC [201,202]. AMPK, a master energy sensor of the cell, has long been recognized in metabolic disorders and was also found to be a tumor suppressor in HCC $[203,204]$. In instances of nutrient deprivation and accumulation of cellular AMP, AMPK becomes activated to perform inhibitory phosphorylation of acetylCoA carboxylase (ACC). In hepatocytes, the two isoforms ACC1 and ACC2 are found in the cytosol and mitochondria, respectively, and function to convert acetyl-coenzyme A (acetyl-CoA) to malonyl-CoA, the rate-limiting step of de novo lipogenesis [205]. MalonylCoA inhibits carnitine palmitoyltransferase 1 (CPT1) to suppress fatty acid transport for mitochondrial beta oxidation. Therefore, in theory, ACC inhibition should decrease hepatic lipogenesis and promote fatty acid oxidation to blunt NAFLD progression. ACC inhibitors were found to reduce liver steatosis and insulin resistance in rodent models, though may worsen dyslipidemia [206-208]. Firsocostat (GS-0976), a dual ACC1/ACC2 inhibitor, reduced liver steatosis and serum markers of fibrosis in an early clinical trial $[209,210]$, though unfortunately a recent phase 2 trial did not show similar efficacy and meet the study's primary endpoint of fibrosis improvement (NCT03449446). Other ACC inhibitors are also being evaluated in clinical trials and have shown to reduce hepatic de novo lipogenesis [211]. In addition to reducing liver steatosis, ACC inhibition has also been shown to play an independent therapeutic role in HCC [212]. ACC and other targets of hepatic lipogenesis and fatty acid oxidation could modulate lipid metabolism to treat NAFLD and confer additional antitumorigenic effects.

\subsection{Statins}

The rate-limiting step of de novo cholesterol synthesis is carried out by 3-hydroxy3-methylglutaryl-coenzyme A reductase (HMGR) [213]. Statins inhibit HMGR and are most known for their role in the treatment of dyslipidemia which confers primary and secondary prevention of cardiovascular disease. The high rates of dyslipidemia and statin use have allowed for powerful retrospective analyses. In regard to NAFLD, systematic reviews and meta-analyses have demonstrated a possible decrease in serum aminotransferase levels and steatosis on ultrasound though histological results were limited and conflicting [214-216]. However, numerous reviews focused on statins in the context of HCC have consistently demonstrated a negative correlation between statin use and tumor formation in liver disease of various etiology [217-223]. Additionally, in vitro studies and preclinical animal models have demonstrated this antitumorigenic effect with c-myc and IL-6/STAT3 pathways implicated [224-226]. Overall, there appears to be evidence for potential statin-mediated independent antitumorigenic effects in HCC making them suitable agents for chemoprevention or even adjuvant therapy, though these epidemiologic 
data are limited by their retrospective nature and prospective randomized trials are needed. While statins are associated with liver enzyme elevations, they have been shown to be safe in NAFLD patients without decompensated cirrhosis [227]. NAFLD patients often present with concomitant dyslipidemia in which case statin therapy is recommended. The use of statin therapy may reduce HCC risk in non-dyslipidemic NAFLD patients and serve a role in chemoprevention, though it is not currently indicated. While it will not be discussed in detail, metformin similarly has not consistently prevented NAFLD progression though strong epidemiologic data and preclinical models show its chemopreventive effects in HCC through alterations in AMPK and ACC pathways.

\section{Future Perspectives}

\subsection{Gut Microbiome}

Knowledge of the gut microbiome's relationship to human health and disease has rapidly advanced over the last decade $[228,229]$. These organisms populate the gastrointestinal tract, where they alter dietary food substrates and secrete a host of effector metabolites. Microbes affect host physiology directly through cell membrane components ex. endotoxins/lipopolysaccharides, and indirectly through metabolite mediators ex. short-chain fatty acids and secondary bile acids. This rapidly growing field of study has led to discoveries related to cardiovascular disease, inflammatory bowel disease, and liver disease, among others $[228,230]$. The anatomic location of the liver links it closely as an effector organ of gut microbe physiology as gastrointestinal metabolites primarily drain into the portal venous circulation for initial delivery to the liver prior to entrance into the systemic circulation. This design places the liver in prime position to serve as a biotransformation factory of these molecules and there is now strong interest of the gut microbiome's relationship to both NAFLD and HCC [230,231].

Strong associations between the gut microbiome and NAFLD have been made [230]. Alterations in the gut microbial composition (dysbiosis) and gut membrane integrity have been strongly linked to liver disease, especially in patients with late-stage fibrosis and cirrhosis. Dysbiosis leads to dysregulation of bile acid homeostasis, local and systemic inflammation, and the release of pathogen- and microbial-associated molecular patterns (PAMPs/MAMPs) and microbial metabolites. Compromised gut membrane integrity exaggerates these effects. Diagnostic and therapeutic options are now being considered [232]. Gut microbe composition may serve as a useful tool for non-invasive diagnosis and severity assessment of NAFLD. Correcting dysbiosis through dietary interventions and pro-, pre-, and synbiotics are under active investigation as well as the use of postbiotics, antibiotics, fecal microbiota transplantation, and bacteriophage therapy. Methods to reduce NAFLD-promoting pathways that arise from exposure to harmful microbial components and metabolites are being explored. These include improving gut membrane integrity, targeting liver physiology such as through toll-like receptor (TLR) inhibition, and even altering bacterial gene pathways to improve the microbial-produced metabolome. A prime example of this last point is the investigation of choline trimethylamine (TMA)-lyase (CutC) inhibitors to reduce bacterial generation of the harmful microbial-metabolite TMA [233].

The association of dysbiosis and altered gut membrane integrity in HCC has been established [231], though may be confounded by the impact of coexisting cirrhosis. The microbiome appears to play an independent role in hepatocarcinogenesis in addition to promoting liver injury and NAFLD as discussed above, though studies have been primarily done in animal models and are limited by a lack of human clinical data. Rodent models demonstrate the contribution of the gut microbiome in tumor development, as germ-free and microbiome-ablated animals are protected from HCC development [231]. In line with this, treatment with MAMPs and compounds that impair gut membrane permeability lead to increased tumor burden. Pro-tumorigenic mechanisms implicated include the activation of hepatic TLRs by bacterial endotoxin, altered bile acid metabolism with increased levels of deoxycholic acid, production of hepatotoxic metabolites such as TMA, and alterations in 
immune cell activation and immunosurveillance $[231,234]$. Future studies are needed to better delineate mechanistic pathways and identify therapeutic opportunities.

\subsection{Lipotoxicity and Autophagy}

An abundance of literature exists on the pathogenesis of NAFLD and of HCC, though usually independent from one another. Interest of overlapping pathogenic mechanisms has grown due to the rise in NAFLD-related HCC and the recognition of metabolic syndrome's negative effects on HCC of various etiology. A review on this was written by Anstee et al. and emphasized the importance of oxidative stress, DNA damage, and autophagy in NAFLD progression and HCC development [235]. An excellent review series on lipotoxicity-mediated cell dysfunction nicely illustrates pathogenic mechanisms in the development and progression of NAFLD that closely relate to hepatocarcinogenesis [236-240]. These will serve as the basis of Figure 2 and the following paragraphs to highlight an untapped potential in the approach to NAFLD and its progression to HCC.

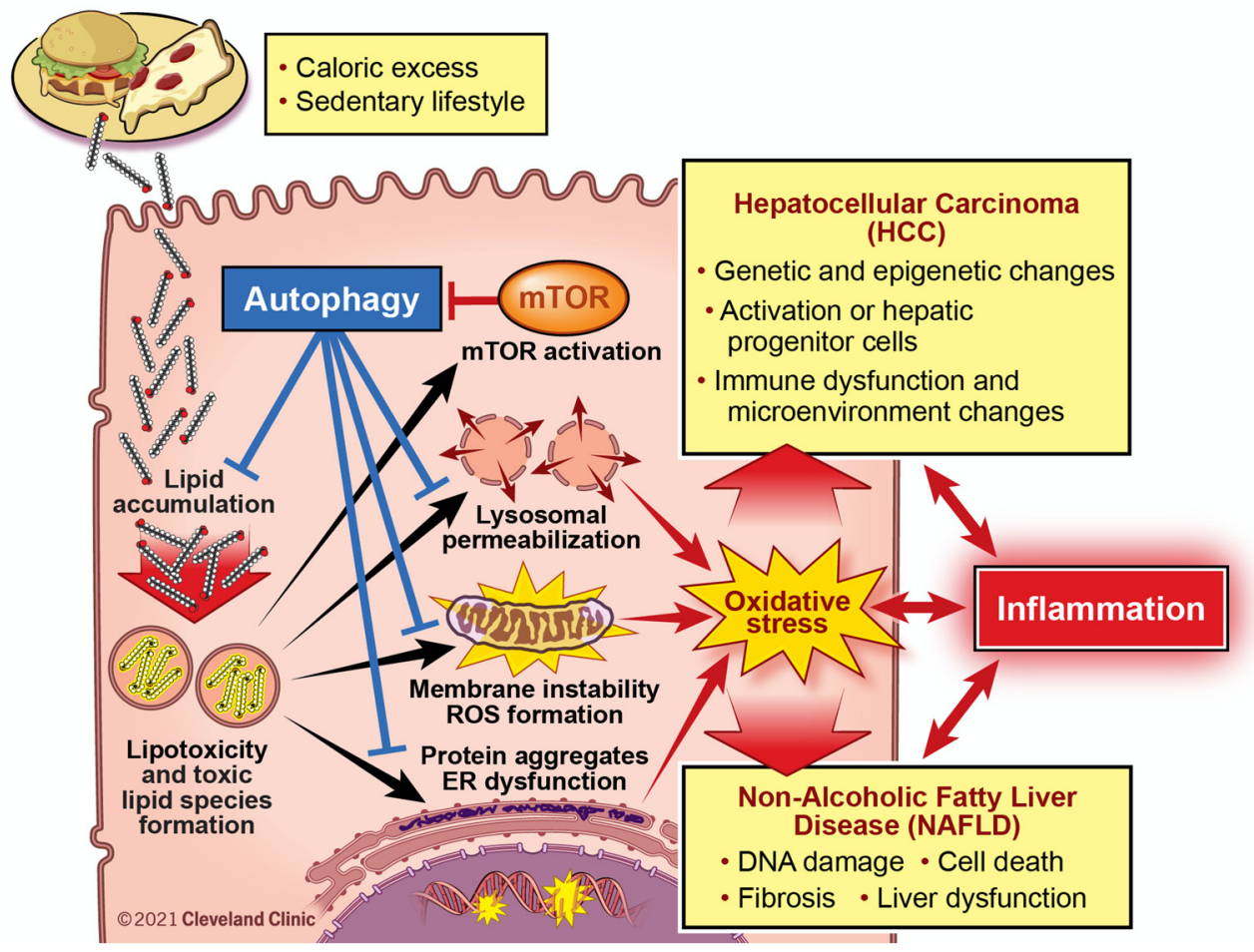

Figure 2. Targeting Lipotoxicity-Driven Pathways to Reduce NAFLD Progression and Prevent HCC Development. The initiating event in NAFLD is lipid accumulation, and it is generally accepted that "lipotoxicity" occurs where intermediates in lipid biosynthesis can act as signaling molecules or alter other cellular processes to promote liver disease. Lipotoxicity is associated with many cellular pathways including increased oxidative stress, endoplasmic reticulum (ER) stress, mitochondrial dysfunction with reactive oxygen species (ROS) formation, and lysosomal dysfunction with lysosomal membrane permeabilization (LMP). Collectively, the pathways initiated by lipotoxicity may lead to NAFLD progression via DNA damage and cell death, inflammatory cell recruitment, activation of pro-fibrotic programs, as well as local and systemic insults. Autophagy is central to several of these lipotoxicity-driven pathways, and therapies impacting autophagic flux during NAFLD progression may hold promise.

NAFLD is characterized by liver steatosis, the accumulation of fat deposition within the liver. Hepatic free fatty acid accumulation generates a host of toxic lipid intermediates to trigger various forms of cell stress $[237,238]$. This phenomenon known as "lipotoxicity" is ultimately the driver of NAFLD and should be maintained as a major focus in targeting pathogenic mechanisms. Lipotoxicity involves the accumulation of $\alpha, \beta$ polyunsaturated 
lipid aldehydes and other toxic lipid intermediates such as palmitate and lysophosphatidylcholine, leading to endoplasmic reticulum stress, mitochondrial dysfunction, and lysosomal stress. These culminate in oxidative stress, which itself can exacerbate cell dysfunction creating a vicious positive feedback loop. Oxidative stress in NAFLD and its relationship with hepatocyte injury, immune system activation, and collagen deposition by hepatic stellate cells has been nicely reviewed elsewhere [241-244]. These insults promote NAFLD progression through processes involving DNA damage, cell death, local and systemic inflammation, fibrosis, and liver dysfunction $[8,235]$. These work together to promote HCC development and progression via the activation of oncogenes and inhibition of tumor suppressor genes, aberrant cell cycle regulation, activation of hepatic progenitor cells, and immune dysfunction along with a tumor-promoting microenvironment [235,245-247].

Autophagy is known for its "self-eating" functions serving to maintain cellular homeostasis through organelle recycling, especially during periods of starvation [239]. Autophagy and lysosomal pathways function in various ways to limit the lipotoxicitymediated pathways listed above [239]. Lipophagy, a subset of autophagy, works to reduce lipid accumulation when canonical lipid catabolic pathways are overwhelmed. Additionally, autophagy in concert with lysosomes promotes lipid turnover to prevent accumulation of toxic lipid intermediates. If ER stress pathways and the unfolded protein response are unable to maintain cellular protein homeostasis, autophagy is stimulated to degrade misfolded and aggregated proteins. Mitochondrial and lysosomal health are maintained by autophagy through mitophagy and lysosomal membrane turnover. Lastly, autophagy functions as a critical component of the cellular antioxidant response to reduce ROS formation and cell damage [248], and by doing so also prevents various mechanisms linked to hepatocarcinogenesis [249]. As such, autophagy promotes cellular health in the face of lipid overload and is an attractive target in the treatment of NAFLD. Additionally, it plays critical roles in cellular differentiation [250], cell cycle regulation [251], and the modulation of tumor microenvironments [252], and has been implicated in numerous cancers including HCC though its role in treatment is unclear $[249,253]$.

The mammalian target of rapamycin (mTOR), a master nutrient sensor of the cell, is activated by excess free fatty acid and carbohydrate and acts as a repressor of autophagy [254]. mTOR activation has been strongly linked to both NAFLD and HCC. In the latter, mTOR was found to be upregulated in approximately $50 \%$ of human tumors and associated with poorer prognosis [254], with one study implicating it directly promotes tumorigenesis through lipid synthesis [255]. Inhibitors of mTOR (rapamycin and analogs) are being used in the treatment of other cancers and are being investigated in the treatment of HCC though have not shown a clear benefit [256]. No prospective studies have been done to discern their chemopreventive potential. As autophagy promotes cellular health under normal conditions and periods of starvation, there is concern it may act as a double-edged sword to promote tumor cell health and cancer progression. Overall, however, this notion is not well supported by in vitro cell culture models, preclinical animal models, or human data.

With the exception of the antioxidant vitamin E, the lipotoxicity-mediated pathways outlined above (Figure 2) have remained largely untapped in the treatment of NAFLD and may serve as powerful adjuncts in the chemoprevention of NAFLD-related HCC. A precise therapeutic induction of autophagy or modulation of related endocytic and lysosomal pathways may serve to modulate several pathogenic mechanisms simultaneously. New approaches to harness the beneficial effects of autophagy on liver disease are being considered. Studies using intermittent fasting (NCT04355910) and second-generation mTOR inhibitors are especially exciting $[256,257]$. New therapeutic options may open in the form of monotherapy or in combination with other treatments. A better understanding of these mechanisms along with their complex interrelationships is needed.

\section{Conclusions}

Rates of metabolic syndrome and NAFLD continue to rise globally. Although HCC was classically thought of as a disease initiated by viral hepatitis, effective antiviral thera- 
pies are now available and NAFLD continues to gain ground as a leading cause of chronic liver disease and HCC. The treatment of NAFLD has remained largely unchanged and it is expected that rates of NAFLD-related HCC will continue to sharply rise. New treatment approaches are needed. The current paradigm of NAFLD treatment focuses on improving markers of liver injury and fibrosis, though the prevention of HCC should also be considered. Pathogenic mechanisms common to both NAFLD and HCC may also serve as targets for chemoprevention. Metabolic syndrome promotes tumor formation and progression in non-NAFLD-related HCC, and a similar chemopreventive approach in these patients targeting metabolically relevant pathways may prove beneficial.

The pathogenesis of NAFLD encompasses aberrant lipid and nutrient homeostasis within a complex web of cellular pathways. These intricate pathways working in tandem to achieve a delicate system of checks and balances may be responsible for the failure rates that have plagued NAFLD clinical trials. Combination therapy to simultaneously manipulate these mechanisms of disease may help to overcome this pharmacologic challenge and increase chances of therapeutic success. While awaiting more effective NAFLD treatments, adopting a strategy of primary prevention against HCC in these patients may be useful. Several therapeutic targets have demonstrated potential in reducing HCC development in NAFLD and prospective trials are needed. A better understanding of pathways linking the progression of NAFLD to tumorigenesis may be used to develop treatment strategies to mitigate the development of $\mathrm{HCC}$ and its complications in these patients.

Author Contributions: Conceptualization, D.O. and J.M.B.; writing-original draft preparation, D.O.; writing-review and editing, D.O., N.A.B. and J.M.B. All authors have read and agreed to the published version of the manuscript.

Funding: This work was supported in part by National Institutes of Health grants R01 DK120679 (J.M.B.), P50 AA024333 (J.M.B.), P01 HL147823 (J.M.B.), P50 CA150964 (N.A.B.), and P30 CA043703 (N.A.B.).

Acknowledgments: We would like to thank David R. Schumick for generating the figure illustrations for this manuscript.

Conflicts of Interest: The authors declare no conflict of interest.

\section{References}

1. Siegel, R.L.; Miller, K.D.; Jemal, A. Cancer Statistics, 2018. CA Cancer J. Clin. 2018, 68, 7-30. [CrossRef]

2. Dasgupta, P.; Henshaw, C.; Youlden, D.R.; Clark, P.J.; Aitken, J.F.; Baade, P.D. Global Trends in Incidence Rates of Primary Adult Liver Cancers: A Systematic Review and Meta-Analysis. Front. Oncol. 2020, 10, 171. [CrossRef]

3. Younossi, Z.M.; Otgonsuren, M.; Henry, L.; Venkatesan, C.; Mishra, A.; Erario, M.; Hunt, S. Association of Nonalcoholic Fatty Liver Disease (NAFLD) with Hepatocellular Carcinoma (HCC) in the United States from 2004 to 2009. Hepatol. Baltim. Md 2015, 62, 1723-1730. [CrossRef]

4. Huang, D.Q.; El-Serag, H.B.; Loomba, R. Global Epidemiology of NAFLD-Related HCC: Trends, Predictions, Risk Factors and Prevention. Nat. Rev. Gastroenterol. Hepatol. 2020, 1-16. [CrossRef]

5. McGlynn, K.A.; Petrick, J.L.; El-Serag, H.B. Epidemiology of Hepatocellular Carcinoma. Hepatol. Baltim. Md 2021, 73 (Suppl. 1), 4-13. [CrossRef]

6. Steele, C.B. Vital Signs: Trends in Incidence of Cancers Associated with Overweight and Obesity-United States, 2005-2014. MMWR Morb. Mortal. Wkly. Rep. 2017, 66, 1052-1058. [CrossRef]

7. Chalasani, N.; Younossi, Z.; Lavine, J.E.; Charlton, M.; Cusi, K.; Rinella, M.; Harrison, S.A.; Brunt, E.M.; Sanyal, A.J. The Diagnosis and Management of Nonalcoholic Fatty Liver Disease: Practice Guidance from the American Association for the Study of Liver Diseases. Hepatology 2018, 67, 328-357. [CrossRef] [PubMed]

8. Parthasarathy, G.; Revelo, X.; Malhi, H. Pathogenesis of Nonalcoholic Steatohepatitis: An Overview. Hepatol. Commun. 2020, 4, 478-492. [CrossRef] [PubMed]

9. Younossi, Z.M.; Loomba, R.; Rinella, M.E.; Bugianesi, E.; Marchesini, G.; Neuschwander-Tetri, B.A.; Serfaty, L.; Negro, F.; Caldwell, S.H.; Ratziu, V.; et al. Current and Future Therapeutic Regimens for Nonalcoholic Fatty Liver Disease and Nonalcoholic Steatohepatitis. Hepatol. Baltim. Md 2018, 68, 361-371. [CrossRef] [PubMed]

10. Baffy, G.; Brunt, E.M.; Caldwell, S.H. Hepatocellular Carcinoma in Non-Alcoholic Fatty Liver Disease: An Emerging Menace. J. Hepatol. 2012, 56, 1384-1391. [CrossRef] [PubMed]

11. Pelusi, S.; Baselli, G.; Pietrelli, A.; Dongiovanni, P.; Donati, B.; McCain, M.V.; Meroni, M.; Fracanzani, A.L.; Romagnoli, R.; Petta, S.; et al. Rare Pathogenic Variants Predispose to Hepatocellular Carcinoma in Nonalcoholic Fatty Liver Disease. Sci. Rep. 2019, 9, 3682. [CrossRef] 
12. Eslam, M.; Sanyal, A.J.; George, J. International Consensus Panel MAFLD: A Consensus-Driven Proposed Nomenclature for Metabolic Associated Fatty Liver Disease. Gastroenterology 2020, 158, 1999-2014.e1. [CrossRef] [PubMed]

13. Younossi, Z.M.; Koenig, A.B.; Abdelatif, D.; Fazel, Y.; Henry, L.; Wymer, M. Global Epidemiology of Nonalcoholic Fatty Liver Disease-Meta-Analytic Assessment of Prevalence, Incidence, and Outcomes. Hepatol. Baltim. Md 2016, 64, 73-84. [CrossRef]

14. Vernon, G.; Baranova, A.; Younossi, Z.M. Systematic Review: The Epidemiology and Natural History of Non-Alcoholic Fatty Liver Disease and Non-Alcoholic Steatohepatitis in Adults. Aliment. Pharmacol. Ther. 2011, 34, 274-285. [CrossRef] [PubMed]

15. Lonardo, A.; Nascimbeni, F.; Ballestri, S.; Fairweather, D.; Win, S.; Than, T.A.; Abdelmalek, M.F.; Suzuki, A. Sex Differences in NAFLD: State of the Art and Identification of Research Gaps. Hepatol. Baltim. Md 2019, 70, 1457-1469. [CrossRef] [PubMed]

16. Perumpail, B.J.; Khan, M.A.; Yoo, E.R.; Cholankeril, G.; Kim, D.; Ahmed, A. Clinical Epidemiology and Disease Burden of Nonalcoholic Fatty Liver Disease. World J. Gastroenterol. 2017, 23, 8263-8276. [CrossRef]

17. Younossi, Z.; Anstee, Q.M.; Marietti, M.; Hardy, T.; Henry, L.; Eslam, M.; George, J.; Bugianesi, E. Global Burden of NAFLD and NASH: Trends, Predictions, Risk Factors and Prevention. Nat. Rev. Gastroenterol. Hepatol. 2018, 15, 11-20. [CrossRef]

18. Younossi, Z.M.; Stepanova, M.; Afendy, M.; Fang, Y.; Younossi, Y.; Mir, H.; Srishord, M. Changes in the Prevalence of the Most Common Causes of Chronic Liver Diseases in the United States from 1988 to 2008. Clin. Gastroenterol. Hepatol. Off. Clin. Pract. J. Am. Gastroenterol. Assoc. 2011, 9, 524-530.e1. [CrossRef]

19. van der Poorten, D.; Samer, C.F.; Ramezani-Moghadam, M.; Coulter, S.; Kacevska, M.; Schrijnders, D.; Wu, L.E.; McLeod, D.; Bugianesi, E.; Komuta, M.; et al. Hepatic Fat Loss in Advanced Nonalcoholic Steatohepatitis: Are Alterations in Serum Adiponectin the Cause? Hepatol. Baltim. Md 2013, 57, 2180-2188. [CrossRef]

20. Kogiso, T.; Tokushige, K. The Current View of Nonalcoholic Fatty Liver Disease-Related Hepatocellular Carcinoma. Cancers 2021, 13, 516. [CrossRef]

21. Brar, G.; Greten, T.F.; Graubard, B.I.; McNeel, T.S.; Petrick, J.L.; McGlynn, K.A.; Altekruse, S.F. Hepatocellular Carcinoma Survival by Etiology: A SEER-Medicare Database Analysis. Hepatol. Commun. 2020, 4, 1541-1551. [CrossRef] [PubMed]

22. El-Serag, H.B.; Kanwal, F. Epidemiology of Hepatocellular Carcinoma in the United States: Where Are We? Where Do We Go? Hepatol. Baltim. Md 2014, 60, 1767-1775. [CrossRef]

23. Kanwal, F.; Kramer, J.R.; Mapakshi, S.; Natarajan, Y.; Chayanupatkul, M.; Richardson, P.A.; Li, L.; Desiderio, R.; Thrift, A.P.; Asch, S.M.; et al. Risk of Hepatocellular Cancer in Patients With Non-Alcoholic Fatty Liver Disease. Gastroenterology 2018, 155, 1828-1837.e2. [CrossRef] [PubMed]

24. Wong, R.J.; Cheung, R.; Ahmed, A. Nonalcoholic Steatohepatitis Is the Most Rapidly Growing Indication for Liver Transplantation in Patients with Hepatocellular Carcinoma in the US. Hepatology 2014, 59, 2188-2195. [CrossRef]

25. Huang, P.L. A Comprehensive Definition for Metabolic Syndrome. Dis. Model. Mech. 2009, 2, 231-237. [CrossRef]

26. Saklayen, M.G. The Global Epidemic of the Metabolic Syndrome. Curr. Hypertens. Rep. 2018, 20, 12. [CrossRef] [PubMed]

27. Yki-Järvinen, H. Non-Alcoholic Fatty Liver Disease as a Cause and a Consequence of Metabolic Syndrome. Lancet Diabetes Endocrinol. 2014, 2, 901-910. [CrossRef]

28. Utzschneider, K.M.; Kahn, S.E. The Role of Insulin Resistance in Nonalcoholic Fatty Liver Disease. J. Clin. Endocrinol. Metab. 2006, 91, 4753-4761. [CrossRef]

29. Scherer, P.E. Adipose Tissue: From Lipid Storage Compartment to Endocrine Organ. Diabetes 2006, 55, 1537-1545. [CrossRef]

30. Kusminski, C.M.; Bickel, P.E.; Scherer, P.E. Targeting Adipose Tissue in the Treatment of Obesity-Associated Diabetes. Nat. Rev. Drug Discov. 2016, 15, 639-660. [CrossRef]

31. Fryar, C.; Carroll, M.; Afful, J. Prevalence of Overweight, Obesity, and Severe Obesity among Adults Aged 20 and over: United States, 1960-1962 through 2017-2018. NCHS Health E-Stats, 2020. Available online: https://www.cdc.gov/nchs/data/hestat/ obesity-adult-17-18/obesity-adult.htm (accessed on 3 March 2021).

32. Ng, M.; Fleming, T.; Robinson, M.; Thomson, B.; Graetz, N.; Margono, C.; Mullany, E.C.; Biryukov, S.; Abbafati, C.; Abera, S.F.; et al. Global, Regional, and National Prevalence of Overweight and Obesity in Children and Adults during 1980-2013: A Systematic Analysis for the Global Burden of Disease Study 2013. Lancet 2014, 384, 766-781. [CrossRef]

33. Fan, R.; Wang, J.; Du, J. Association between Body Mass Index and Fatty Liver Risk: A Dose-Response Analysis. Sci. Rep. 2018, 8, 15273. [CrossRef] [PubMed]

34. Li, L.; Liu, D.-W.; Yan, H.-Y.; Wang, Z.-Y.; Zhao, S.-H.; Wang, B. Obesity Is an Independent Risk Factor for Non-Alcoholic Fatty Liver Disease: Evidence from a Meta-Analysis of 21 Cohort Studies. Obes. Rev. Off. J. Int. Assoc. Study Obes. $2016,17,510-519$. [CrossRef]

35. Koh, J.C.; Loo, W.M.; Goh, K.L.; Sugano, K.; Chan, W.K.; Chiu, W.Y.P.; Choi, M.-G.; Gonlachanvit, S.; Lee, W.-J.; Lee, W.J.J.; et al. Asian Consensus on the Relationship between Obesity and Gastrointestinal and Liver Diseases. J. Gastroenterol. Hepatol. 2016, 31, 1405-1413. [CrossRef]

36. Welzel, T.M.; Graubard, B.I.; Zeuzem, S.; El-Serag, H.B.; Davila, J.A.; McGlynn, K.A. Metabolic Syndrome Increases the Risk of Primary Liver Cancer in the United States: A Population-Based Case-Control Study. Hepatol. Baltim. Md 2011, 54, 463-471. [CrossRef] [PubMed]

37. Larsson, S.C.; Wolk, A. Overweight, Obesity and Risk of Liver Cancer: A Meta-Analysis of Cohort Studies. Br. J. Cancer 2007, 97, 1005-1008. [CrossRef] 
38. Chen, C.-L.; Yang, H.-I.; Yang, W.-S.; Liu, C.-J.; Chen, P.-J.; You, S.-L.; Wang, L.-Y.; Sun, C.-A.; Lu, S.-N.; Chen, D.-S.; et al. Metabolic Factors and Risk of Hepatocellular Carcinoma by Chronic Hepatitis B/C Infection: A Follow-up Study in Taiwan. Gastroenterology 2008, 135, 111-121. [CrossRef] [PubMed]

39. Ohki, T.; Tateishi, R.; Sato, T.; Masuzaki, R.; Imamura, J.; Goto, T.; Yamashiki, N.; Yoshida, H.; Kanai, F.; Kato, N.; et al. Obesity Is an Independent Risk Factor for Hepatocellular Carcinoma Development in Chronic Hepatitis C Patients. Clin. Gastroenterol. Hepatol. 2008, 6, 459-464. [CrossRef] [PubMed]

40. Loomba, R.; Yang, H.-I.; Su, J.; Brenner, D.; Barrett-Connor, E.; Iloeje, U.; Chen, C.-J. Synergism between Obesity and Alcohol in Increasing the Risk of Hepatocellular Carcinoma: A Prospective Cohort Study. Am. J. Epidemiol. 2013, 177, 333-342. [CrossRef]

41. Lee, J.; Yoo, S.H.; Sohn, W.; Kim, H.W.; Choi, Y.S.; Won, J.H.; Heo, J.Y.; Park, S.J.; Park, Y.M. Obesity and Hepatocellular Carcinoma in Patients Receiving Entecavir for Chronic Hepatitis B. Clin. Mol. Hepatol. 2016, 22, 339-349. [CrossRef] [PubMed]

42. Cha, B.; Yu, J.H.; Jin, Y.-J.; Suh, Y.J.; Lee, J.-W. Survival Outcomes According to Body Mass Index in Hepatocellular Carcinoma Patient: Analysis of Nationwide Cancer Registry Database. Sci. Rep. 2020, 10, 8347. [CrossRef]

43. Yoshimoto, S.; Loo, T.M.; Atarashi, K.; Kanda, H.; Sato, S.; Oyadomari, S.; Iwakura, Y.; Oshima, K.; Morita, H.; Hattori, M.; et al. Obesity-Induced Gut Microbial Metabolite Promotes Liver Cancer through Senescence Secretome. Nature 2013, 499, 97-101. [CrossRef]

44. Zhang, H.E.; Henderson, J.M.; Gorrell, M.D. Animal Models for Hepatocellular Carcinoma. Biochim. Biophys. Acta (BBA) Mol. Basis Dis. 2019, 1865, 993-1002. [CrossRef]

45. Duan, X.-F.; Tang, P.; Li, Q.; Yu, Z.-T. Obesity, Adipokines and Hepatocellular Carcinoma. Int. J. Cancer 2013, $133,1776-1783$. [CrossRef]

46. Katsiki, N.; Mikhailidis, D.P.; Mantzoros, C.S. Non-Alcoholic Fatty Liver Disease and Dyslipidemia: An Update. Metab. Clin. Exp. 2016, 65, 1109-1123. [CrossRef] [PubMed]

47. Wu, K.-T.; Kuo, P.-L.; Su, S.-B.; Chen, Y.-Y.; Yeh, M.-L.; Huang, C.-I.; Yang, J.-F.; Lin, C.-I.; Hsieh, M.-H.; Hsieh, M.-Y.; et al. Nonalcoholic Fatty Liver Disease Severity Is Associated with the Ratios of Total Cholesterol and Triglycerides to High-Density Lipoprotein Cholesterol. J. Clin. Lipidol. 2016, 10, 420-425.e1. [CrossRef]

48. Liu, X.; Li, M.; Wang, X.; Dang, Z.; Jiang, Y.; Wang, X.; Yang, Z. Effect of Serum Triglyceride Level on the Prognosis of Patients with Hepatocellular Carcinoma in the Absence of Cirrhosis. Lipids Health Dis. 2018, 17, 248. [CrossRef] [PubMed]

49. Chiang, C.-H.; Lee, L.-T.; Hung, S.-H.; Lin, W.-Y.; Hung, H.-F.; Yang, W.-S.; Sung, P.-K.; Huang, K.-C. Opposite Association between Diabetes, Dyslipidemia, and Hepatocellular Carcinoma Mortality in the Middle-Aged and Elderly. Hepatology 2014, 59, 2207-2215. [CrossRef] [PubMed]

50. Muoio, D.M.; Newgard, C.B. Molecular and Metabolic Mechanisms of Insulin Resistance and $\beta$-Cell Failure in Type 2 Diabetes. Nat. Rev. Mol. Cell Biol. 2008, 9, 193-205. [CrossRef] [PubMed]

51. Khan, R.S.; Bril, F.; Cusi, K.; Newsome, P.N. Modulation of Insulin Resistance in Nonalcoholic Fatty Liver Disease. Hepatol. Baltim. Md 2019, 70, 711-724. [CrossRef]

52. Hassan, M.M.; Curley, S.A.; Li, D.; Kaseb, A.; Davila, M.; Abdalla, E.K.; Javle, M.; Moghazy, D.M.; Lozano, R.D.; Abbruzzese, J.L.; et al. Association of Diabetes Duration and Diabetes Treatment with the Risk of Hepatocellular Carcinoma. Cancer 2010, 116, 1938-1946. [CrossRef] [PubMed]

53. Davila, J.A.; Morgan, R.O.; Shaib, Y.; McGlynn, K.A.; El-Serag, H.B. Diabetes Increases the Risk of Hepatocellular Carcinoma in the United States: A Population Based Case Control Study. Gut 2005, 54, 533-539. [CrossRef] [PubMed]

54. Wang, P.; Kang, D.; Cao, W.; Wang, Y.; Liu, Z. Diabetes Mellitus and Risk of Hepatocellular Carcinoma: A Systematic Review and Meta-Analysis. Diabetes Metab. Res. Rev. 2012, 28, 109-122. [CrossRef] [PubMed]

55. Kohjima, M.; Higuchi, N.; Kato, M.; Kotoh, K.; Yoshimoto, T.; Fujino, T.; Yada, M.; Yada, R.; Harada, N.; Enjoji, M.; et al. SREBP-1c, Regulated by the Insulin and AMPK Signaling Pathways, Plays a Role in Nonalcoholic Fatty Liver Disease. Int. J. Mol. Med. 2008, 21, 507-511. [CrossRef]

56. Sakurai, Y.; Kubota, N.; Takamoto, I.; Obata, A.; Iwamoto, M.; Hayashi, T.; Aihara, M.; Kubota, T.; Nishihara, H.; Kadowaki, T. Role of Insulin Receptor Substrates in the Progression of Hepatocellular Carcinoma. Sci. Rep. 2017, 7, 5387. [CrossRef]

57. Li, C.; Yang, W.; Zhang, J.; Zheng, X.; Yao, Y.; Tu, K.; Liu, Q. SREBP-1 Has a Prognostic Role and Contributes to Invasion and Metastasis in Human Hepatocellular Carcinoma. Int. J. Mol. Sci. 2014, 15, 7124-7138. [CrossRef]

58. Angulo, P.; Kleiner, D.E.; Dam-Larsen, S.; Adams, L.A.; Bjornsson, E.S.; Charatcharoenwitthaya, P.; Mills, P.R.; Keach, J.C.; Lafferty, H.D.; Stahler, A.; et al. Liver Fibrosis, but No Other Histologic Features, Is Associated With Long-Term Outcomes of Patients With Nonalcoholic Fatty Liver Disease. Gastroenterology 2015, 149, 389-397.e10. [CrossRef]

59. Argo, C.K.; Northup, P.G.; Al-Osaimi, A.M.S.; Caldwell, S.H. Systematic Review of Risk Factors for Fibrosis Progression in Non-Alcoholic Steatohepatitis. J. Hepatol. 2009, 51, 371-379. [CrossRef]

60. Eguchi, Y.; Wong, G.; Akhtar, O.; Sumida, Y. Non-Invasive Diagnosis of Non-Alcoholic Steatohepatitis and Advanced Fibrosis in Japan: A Targeted Literature Review. Hepatol. Res. 2020, 50, 645-655. [CrossRef]

61. Musso, G.; Cassader, M.; Rosina, F.; Gambino, R. Impact of Current Treatments on Liver Disease, Glucose Metabolism and Cardiovascular Risk in Non-Alcoholic Fatty Liver Disease (NAFLD): A Systematic Review and Meta-Analysis of Randomised Trials. Diabetologia 2012, 55, 885-904. [CrossRef]

62. Promrat, K.; Kleiner, D.E.; Niemeier, H.M.; Jackvony, E.; Kearns, M.; Wands, J.R.; Fava, J.L.; Wing, R.R. Randomized Controlled Trial Testing the Effects of Weight Loss on Nonalcoholic Steatohepatitis. Hepatol. Baltim. Md 2010, 51, 121-129. [CrossRef] 
63. Vilar-Gomez, E.; Martinez-Perez, Y.; Calzadilla-Bertot, L.; Torres-Gonzalez, A.; Gra-Oramas, B.; Gonzalez-Fabian, L.; Friedman, S.L.; Diago, M.; Romero-Gomez, M. Weight Loss Through Lifestyle Modification Significantly Reduces Features of Nonalcoholic Steatohepatitis. Gastroenterology 2015, 149, 367-378.e5, quiz e14-15. [CrossRef]

64. Keating, S.E.; Hackett, D.A.; George, J.; Johnson, N.A. Exercise and Non-Alcoholic Fatty Liver Disease: A Systematic Review and Meta-Analysis. J. Hepatol. 2012, 57, 157-166. [CrossRef] [PubMed]

65. Kim, D.; Murag, S.; Cholankeril, G.; Cheung, A.; Harrison, S.A.; Younossi, Z.M.; Ahmed, A. Physical Activity, Measured Objectively, Is Associated With Lower Mortality in Patients With Nonalcoholic Fatty Liver Disease. Clin. Gastroenterol. Hepatol. 2020. [CrossRef]

66. Njei, B.; McCarty, T.R.; Sharma, P.; Lange, A.; Najafian, N.; Ngu, J.N.; Ngomba, V.E.; Echouffo-Tcheugui, J.B. Bariatric Surgery and Hepatocellular Carcinoma: A Propensity Score-Matched Analysis. Obes. Surg. 2018, 28, 3880-3889. [CrossRef] [PubMed]

67. Simon, T.G.; Henson, J.; Osganian, S.; Masia, R.; Chan, A.T.; Chung, R.T.; Corey, K.E. Daily Aspirin Use Associated With Reduced Risk For Fibrosis Progression In Patients With Nonalcoholic Fatty Liver Disease. Clin. Gastroenterol. Hepatol. Off. Clin. Pract. J. Am. Gastroenterol. Assoc. 2019, 17, 2776-2784.e4. [CrossRef] [PubMed]

68. Li, Y.; Liu, L.; Wang, B.; Wang, J.; Chen, D. Metformin in Non-Alcoholic Fatty Liver Disease: A Systematic Review and Meta-Analysis. Biomed. Rep. 2013, 1, 57-64. [CrossRef] [PubMed]

69. Sanyal, A.J.; Abdelmalek, M.F.; Suzuki, A.; Cummings, O.W.; Chojkier, M. EPE-A Study Group No Significant Effects of EthylEicosapentanoic Acid on Histologic Features of Nonalcoholic Steatohepatitis in a Phase 2 Trial. Gastroenterology 2014, 147, 377-384.e1. [CrossRef]

70. Marrero, J.A.; Kulik, L.M.; Sirlin, C.B.; Zhu, A.X.; Finn, R.S.; Abecassis, M.M.; Roberts, L.R.; Heimbach, J.K. Diagnosis, Staging, and Management of Hepatocellular Carcinoma: 2018 Practice Guidance by the American Association for the Study of Liver Diseases: Marrero et al. Hepatology 2018, 68, 723-750. [CrossRef]

71. Mittal, S.; El-Serag, H.B.; Sada, Y.H.; Kanwal, F.; Duan, Z.; Temple, S.; May, S.B.; Kramer, J.R.; Richardson, P.A.; Davila, J.A. Hepatocellular Carcinoma in the Absence of Cirrhosis in United States Veterans Is Associated With Nonalcoholic Fatty Liver Disease. Clin. Gastroenterol. Hepatol. Off. Clin. Pract. J. Am. Gastroenterol. Assoc. 2016, 14, 124-131.e1. [CrossRef]

72. Piscaglia, F.; Svegliati-Baroni, G.; Barchetti, A.; Pecorelli, A.; Marinelli, S.; Tiribelli, C.; Bellentani, S. HCC-NAFLD Italian Study Group Clinical Patterns of Hepatocellular Carcinoma in Nonalcoholic Fatty Liver Disease: A Multicenter Prospective Study. Hepatol. Baltim. Md 2016, 63, 827-838. [CrossRef] [PubMed]

73. White, D.L.; Kanwal, F.; El-Serag, H.B. Association between Nonalcoholic Fatty Liver Disease and Risk for Hepatocellular Cancer, Based on Systematic Review. Clin. Gastroenterol. Hepatol. Off. Clin. Pract. J. Am. Gastroenterol. Assoc. 2012, 10, 1342-1359.e2. [CrossRef] [PubMed]

74. Wong, C.R.; Nguyen, M.H.; Lim, J.K. Hepatocellular Carcinoma in Patients with Non-Alcoholic Fatty Liver Disease. World J. Gastroenterol. 2016, 22, 8294-8303. [CrossRef]

75. Liss, K.H.H.; Finck, B.N. PPARs and Nonalcoholic Fatty Liver Disease. Biochimie 2017, 136, 65-74. [CrossRef]

76. Tailleux, A.; Wouters, K.; Staels, B. Roles of PPARs in NAFLD: Potential Therapeutic Targets. Biochim. Biophys. Acta BBA Mol. Cell Biol. Lipids 2012, 1821, 809-818. [CrossRef]

77. American Diabetes Association 9. Pharmacologic Approaches to Glycemic Treatment: Standards of Medical Care in Diabetes-2021. Diabetes Care 2021, 44, S111-S124. [CrossRef]

78. Skat-Rørdam, J.; Højland Ipsen, D.; Lykkesfeldt, J.; Tveden-Nyborg, P. A Role of Peroxisome Proliferator-Activated Receptor $\gamma$ in Non-Alcoholic Fatty Liver Disease. Basic Clin. Pharmacol. Toxicol. 2019, 124, 528-537. [CrossRef]

79. Yki-Järvinen, H. Thiazolidinediones. N. Engl. J. Med. 2004, 351, 1106-1118. [CrossRef] [PubMed]

80. Boettcher, E.; Csako, G.; Pucino, F.; Wesley, R.; Loomba, R. Meta-Analysis: Pioglitazone Improves Liver Histology and Fibrosis in Patients with Non-Alcoholic Steatohepatitis. Aliment. Pharmacol. Ther. 2012, 35, 66-75. [CrossRef] [PubMed]

81. Lai, S.-W.; Lin, C.-L.; Liao, K.-F. Association of Hepatocellular Carcinoma with Thiazolidinediones Use. Medicine 2020, 99 , e19833. [CrossRef]

82. Chang, C.-H.; Lin, J.-W.; Wu, L.-C.; Lai, M.-S.; Chuang, L.-M.; Chan, K.A. Association of Thiazolidinediones with Liver Cancer and Colorectal Cancer in Type 2 Diabetes Mellitus. Hepatology 2012, 55, 1462-1472. [CrossRef]

83. Lin, H.C.; Hsu, Y.T.; Kachingwe, B.H.; Hsu, C.Y.; Uang, Y.S.; Wang, L.H. Dose Effect of Thiazolidinedione on Cancer Risk in Type 2 Diabetes Mellitus Patients: A Six-Year Population-Based Cohort Study. J. Clin. Pharm. Ther. 2014, 39, 354-360. [CrossRef]

84. Huang, M.-Y.; Chung, C.-H.; Chang, W.-K.; Lin, C.-S.; Chen, K.-W.; Hsieh, T.-Y.; Chien, W.-C.; Lin, H.-H. The Role of Thiazolidinediones in Hepatocellular Carcinoma Risk Reduction: A Population-Based Cohort Study in Taiwan. Am. J. Cancer Res. 2017, 7, 1606-1616.

85. Lai, S.-W.; Chen, P.-C.; Liao, K.-F.; Muo, C.-H.; Lin, C.-C.; Sung, F.-C. Risk of Hepatocellular Carcinoma in Diabetic Patients and Risk Reduction Associated with Anti-Diabetic Therapy: A Population-Based Cohort Study. Am. J. Gastroenterol. $2012,107,46-52$. [CrossRef]

86. Yip, T.C.-F.; Wong, V.W.-S.; Chan, H.L.-Y.; Tse, Y.-K.; Hui, V.W.-K.; Liang, L.Y.; Lee, H.W.; Lui, G.C.-Y.; Kong, A.P.-S.; Wong, G.L.-H. Thiazolidinediones Reduce the Risk of Hepatocellular Carcinoma and Hepatic Events in Diabetic Patients with Chronic Hepatitis B. J. Viral Hepat. 2020, 27, 904-914. [CrossRef]

87. Blanquicett, C.; Roman, J.; Hart, C.M. Thiazolidinediones as Anti-Cancer Agents. Cancer Ther. 2008, 6, $25-34$. 
88. Li, S.; Ghoshal, S.; Sojoodi, M.; Arora, G.; Masia, R.; Erstad, D.J.; Lanuti, M.; Hoshida, Y.; Baumert, T.F.; Tanabe, K.K.; et al. Pioglitazone Reduces Hepatocellular Carcinoma Development in Two Rodent Models of Cirrhosis. J. Gastrointest. Surg. Off. J. Soc. Surg. Aliment. Tract 2019, 23, 101-111. [CrossRef] [PubMed]

89. Wu, C.-W.; Farrell, G.C.; Yu, J. Functional Role of Peroxisome-Proliferator-Activated Receptor $\gamma$ in Hepatocellular Carcinoma. J. Gastroenterol. Hepatol. 2012, 27, 1665-1669. [CrossRef] [PubMed]

90. Hsu, H.-T.; Chi, C.-W. Emerging Role of the Peroxisome Proliferator-Activated Receptor-Gamma in Hepatocellular Carcinoma. J. Hepatocell. Carcinoma 2014, 1, 127-135. [CrossRef]

91. Shen, B.; Chu, E.S.H.; Zhao, G.; Man, K.; Wu, C.-W.; Cheng, J.T.Y.; Li, G.; Nie, Y.; Lo, C.M.; Teoh, N.; et al. PPARgamma Inhibits Hepatocellular Carcinoma Metastases in Vitro and in Mice. Br. J. Cancer 2012, 106, 1486-1494. [CrossRef] [PubMed]

92. Palakurthi, S.S.; Aktas, H.; Grubissich, L.M.; Mortensen, R.M.; Halperin, J.A. Anticancer Effects of Thiazolidinediones Are Independent of Peroxisome Proliferator-Activated Receptor Gamma and Mediated by Inhibition of Translation Initiation. Cancer Res. 2001, 61, 6213-6218. [PubMed]

93. Feinstein, D.L.; Spagnolo, A.; Akar, C.; Weinberg, G.; Murphy, P.; Gavrilyuk, V.; Dello Russo, C. Receptor-Independent Actions of PPAR Thiazolidinedione Agonists: Is Mitochondrial Function the Key? Biochem. Pharmacol. 2005, 70, 177-188. [CrossRef] [PubMed]

94. Auboeuf, D.; Rieusset, J.; Fajas, L.; Vallier, P.; Frering, V.; Riou, J.P.; Staels, B.; Auwerx, J.; Laville, M.; Vidal, H. Tissue Distribution and Quantification of the Expression of MRNAs of Peroxisome Proliferator-Activated Receptors and Liver X Receptor- $\alpha$ in Humans: No Alteration in Adipose Tissue of Obese and NIDDM Patients. Diabetes 1997, 46, 1319-1327. [CrossRef]

95. Braissant, O.; Foufelle, F.; Scotto, C.; Dauça, M.; Wahli, W. Differential Expression of Peroxisome Proliferator-Activated Receptors (PPARs): Tissue Distribution of PPAR-Alpha, -Beta, and -Gamma in the Adult Rat. Endocrinology 1996, 137, 354-366. [CrossRef] [PubMed]

96. Peters, J.M.; Hennuyer, N.; Staels, B.; Fruchart, J.C.; Fievet, C.; Gonzalez, F.J.; Auwerx, J. Alterations in Lipoprotein Metabolism in Peroxisome Proliferator-Activated Receptor Alpha-Deficient Mice. J. Biol. Chem. 1997, 272, 27307-27312. [CrossRef]

97. Kersten, S.; Seydoux, J.; Peters, J.M.; Gonzalez, F.J.; Desvergne, B.; Wahli, W. Peroxisome Proliferator-Activated Receptor Alpha Mediates the Adaptive Response to Fasting. J. Clin. Investig. 1999, 103, 1489-1498. [CrossRef]

98. Ye, J.M.; Doyle, P.J.; Iglesias, M.A.; Watson, D.G.; Cooney, G.J.; Kraegen, E.W. Peroxisome Proliferator-Activated Receptor (PPAR)-Alpha Activation Lowers Muscle Lipids and Improves Insulin Sensitivity in High Fat-Fed Rats: Comparison with PPAR-Gamma Activation. Diabetes 2001, 50, 411-417. [CrossRef]

99. Stec, D.E.; Gordon, D.M.; Hipp, J.A.; Hong, S.; Mitchell, Z.L.; Franco, N.R.; Robison, J.W.; Anderson, C.D.; Stec, D.F.; Hinds, T.D. Loss of Hepatic PPAR $\alpha$ Promotes Inflammation and Serum Hyperlipidemia in Diet-Induced Obesity. Am. J. Physiol. Regul. Integr. Comp. Physiol. 2019, 317, R733-R745. [CrossRef]

100. Pawlak, M.; Lefebvre, P.; Staels, B. Molecular Mechanism of PPAR $\alpha$ Action and Its Impact on Lipid Metabolism, Inflammation and Fibrosis in Non-Alcoholic Fatty Liver Disease. J. Hepatol. 2015, 62, 720-733. [CrossRef]

101. Chou, C.J.; Haluzik, M.; Gregory, C.; Dietz, K.R.; Vinson, C.; Gavrilova, O.; Reitman, M.L. WY14,643, a Peroxisome ProliferatorActivated Receptor Alpha (PPARalpha ) Agonist, Improves Hepatic and Muscle Steatosis and Reverses Insulin Resistance in Lipoatrophic A-ZIP/F-1 Mice. J. Biol. Chem. 2002, 277, 24484-24489. [CrossRef]

102. Keech, A.; Simes, R.J.; Barter, P.; Best, J.; Scott, R.; Taskinen, M.R.; Forder, P.; Pillai, A.; Davis, T.; Glasziou, P.; et al. Effects of Long-Term Fenofibrate Therapy on Cardiovascular Events in 9795 People with Type 2 Diabetes Mellitus (the FIELD Study): Randomised Controlled Trial. Lancet Lond. Engl. 2005, 366, 1849-1861. [CrossRef]

103. Frick, M.H.; Elo, O.; Haapa, K.; Heinonen, O.P.; Heinsalmi, P.; Helo, P.; Huttunen, J.K.; Kaitaniemi, P.; Koskinen, P.; Manninen, V. Helsinki Heart Study: Primary-Prevention Trial with Gemfibrozil in Middle-Aged Men with Dyslipidemia. Safety of Treatment, Changes in Risk Factors, and Incidence of Coronary Heart Disease. N. Engl. J. Med. 1987, 317, 1237-1245. [CrossRef] [PubMed]

104. Balfour, J.A.; McTavish, D.; Heel, R.C. Fenofibrate. A Review of Its Pharmacodynamic and Pharmacokinetic Properties and Therapeutic Use in Dyslipidaemia. Drugs 1990, 40, 260-290. [CrossRef] [PubMed]

105. Ahmad, J.; Odin, J.; Hayashi, P.H.; Chalasani, N.; Fontana, R.J.; Barnhart, H.; Cirulli, E.T.; Kleiner, D.E.; Hoofnagle, J.H Identification and Characterization of Fenofibrate-Induced Liver Injury. Dig. Dis. Sci. 2017, 62, 3596-3604. [CrossRef] [PubMed]

106. Jacobson, T.A. Myopathy with Statin-Fibrate Combination Therapy: Clinical Considerations. Nat. Rev. Endocrinol. 2009, 5, 507-518. [CrossRef]

107. Fernández-Miranda, C.; Pérez-Carreras, M.; Colina, F.; López-Alonso, G.; Vargas, C.; Solís-Herruzo, J.A. A Pilot Trial of Fenofibrate for the Treatment of Non-Alcoholic Fatty Liver Disease. Dig. Liver Dis. 2008, 40, 200-205. [CrossRef]

108. Bajaj, M.; Suraamornkul, S.; Hardies, L.J.; Glass, L.; Musi, N.; DeFronzo, R.A. Effects of Peroxisome Proliferator-Activated Receptor (PPAR)-Alpha and PPAR-Gamma Agonists on Glucose and Lipid Metabolism in Patients with Type 2 Diabetes Mellitus. Diabetologia 2007, 50, 1723-1731. [CrossRef]

109. Basaranoglu, M.; Acbay, O.; Sonsuz, A. A Controlled Trial of Gemfibrozil in the Treatment of Patients with Nonalcoholic Steatohepatitis. J. Hepatol. 1999, 31, 384. [CrossRef]

110. Athyros, V.G.; Mikhailidis, D.P.; Didangelos, T.P.; Giouleme, O.I.; Liberopoulos, E.N.; Karagiannis, A.; Kakafika, A.I.; Tziomalos, K.; Burroughs, A.K.; Elisaf, M.S. Effect of Multifactorial Treatment on Non-Alcoholic Fatty Liver Disease in Metabolic Syndrome: A Randomised Study. Curr. Med. Res. Opin. 2006, 22, 873-883. [CrossRef] 
111. Laurin, J.; Lindor, K.D.; Crippin, J.S.; Gossard, A.; Gores, G.J.; Ludwig, J.; Rakela, J.; McGill, D.B. Ursodeoxycholic Acid or Clofibrate in the Treatment of Non-Alcohol-Induced Steatohepatitis: A Pilot Study. Hepatol. Baltim. Md 1996, 23, $1464-1467$. [CrossRef]

112. Ishibashi, S.; Yamashita, S.; Arai, H.; Araki, E.; Yokote, K.; Suganami, H.; Fruchart, J.-C.; Kodama, T. Effects of K-877, a Novel Selective PPAR $\alpha$ Modulator (SPPARM $\alpha$ ), in Dyslipidaemic Patients: A Randomized, Double Blind, Active- and PlaceboControlled, Phase 2 Trial. Atherosclerosis 2016, 249, 36-43. [CrossRef]

113. Honda, Y.; Kessoku, T.; Ogawa, Y.; Tomeno, W.; Imajo, K.; Fujita, K.; Yoneda, M.; Takizawa, T.; Saito, S.; Nagashima, Y.; et al. Pemafibrate, a Novel Selective Peroxisome Proliferator-Activated Receptor Alpha Modulator, Improves the Pathogenesis in a Rodent Model of Nonalcoholic Steatohepatitis. Sci. Rep. 2017, 7, 42477. [CrossRef]

114. Sasaki, Y.; Asahiyama, M.; Tanaka, T.; Yamamoto, S.; Murakami, K.; Kamiya, W.; Matsumura, Y.; Osawa, T.; Anai, M.; Fruchart, J.-C.; et al. Pemafibrate, a Selective PPAR $\alpha$ Modulator, Prevents Non-Alcoholic Steatohepatitis Development without Reducing the Hepatic Triglyceride Content. Sci. Rep. 2020, 10, 7818. [CrossRef]

115. Yamashita, S.; Arai, H.; Yokote, K.; Araki, E.; Matsushita, M.; Nojima, T.; Suganami, H.; Ishibashi, S. Efficacy and Safety of Pemafibrate, a Novel Selective Peroxisome Proliferator-Activated Receptor $\alpha$ Modulator (SPPARM $\alpha$ ): Pooled Analysis of Phase 2 and 3 Studies in Dyslipidemic Patients with or without Statin Combination. Int. J. Mol. Sci. 2019, 20, 5537. [CrossRef] [PubMed]

116. Araki, E.; Yamashita, S.; Arai, H.; Yokote, K.; Satoh, J.; Inoguchi, T.; Nakamura, J.; Maegawa, H.; Yoshioka, N.; Tanizawa, Y.; et al. Effects of Pemafibrate, a Novel Selective PPAR $\alpha$ Modulator, on Lipid and Glucose Metabolism in Patients With Type 2 Diabetes and Hypertriglyceridemia: A Randomized, Double-Blind, Placebo-Controlled, Phase 3 Trial. Diabetes Care 2018, 41, 538-546. [CrossRef] [PubMed]

117. Hatanaka, T.; Kakizaki, S.; Saito, N.; Nakano, Y.; Nakano, S.; Hazama, Y.; Yoshida, S.; Hachisu, Y.; Tanaka, Y.; Kashiwabara, K.; et al. Impact of Pemafibrate in Patients with Hypertriglyceridemia and Metabolic Dysfunction-Associated Fatty Liver Disease Pathologically Diagnosed with Non-Alcoholic Steatohepatitis: A Retrospective, Single-Arm Study. Intern. Med. Tokyo Jpn. 2021. [CrossRef]

118. Holden, P.R.; Tugwood, J.D. Peroxisome Proliferator-Activated Receptor Alpha: Role in Rodent Liver Cancer and Species Differences. J. Mol. Endocrinol. 1999, 22, 1-8. [CrossRef]

119. Rao, M.S.; Reddy, J.K. An Overview of Peroxisome Proliferator-Induced Hepatocarcinogenesis. Environ. Health Perspect. 1991, 93, 205-209. [CrossRef]

120. Rao, M.S.; Reddy, J.K. Hepatocarcinogenesis of Peroxisome Proliferators. Ann. N. Y. Acad. Sci. 1996, 804, 573-587. [CrossRef]

121. Bonovas, S.; Nikolopoulos, G.K.; Bagos, P.G. Use of Fibrates and Cancer Risk: A Systematic Review and Meta-Analysis of 17 Long-Term Randomized Placebo-Controlled Trials. PLoS ONE 2012, 7, e45259. [CrossRef] [PubMed]

122. Corton, J.C.; Cunningham, M.L.; Hummer, B.T.; Lau, C.; Meek, B.; Peters, J.M.; Popp, J.A.; Rhomberg, L.; Seed, J.; Klaunig, J.E. Mode of Action Framework Analysis for Receptor-Mediated Toxicity: The Peroxisome Proliferator-Activated Receptor Alpha (PPAR $\alpha$ ) as a Case Study. Crit. Rev. Toxicol. 2014, 44, 1-49. [CrossRef] [PubMed]

123. Corton, J.C.; Peters, J.M.; Klaunig, J.E. The PPAR $\alpha$-Dependent Rodent Liver Tumor Response Is Not Relevant to Humans: Addressing Misconceptions. Arch. Toxicol. 2018, 92, 83-119. [CrossRef] [PubMed]

124. Zhang, N.; Chu, E.S.H.; Zhang, J.; Li, X.; Liang, Q.; Chen, J.; Chen, M.; Teoh, N.; Farrell, G.; Sung, J.J.Y.; et al. Peroxisome Proliferator Activated Receptor Alpha Inhibits Hepatocarcinogenesis through Mediating NF-KB Signaling Pathway. Oncotarget 2014, 5, 8330-8340. [CrossRef] [PubMed]

125. Yamasaki, D.; Kawabe, N.; Nakamura, H.; Tachibana, K.; Ishimoto, K.; Tanaka, T.; Aburatani, H.; Sakai, J.; Hamakubo, T.; Kodama, T.; et al. Fenofibrate Suppresses Growth of the Human Hepatocellular Carcinoma Cell via PPAR $\alpha$-Independent Mechanisms. Eur. J. Cell Biol. 2011, 90, 657-664. [CrossRef]

126. Jiao, H.; Zhao, B. Cytotoxic Effect of Peroxisome Proliferator Fenofibrate on Human HepG2 Hepatoma Cell Line and Relevant Mechanisms. Toxicol. Appl. Pharmacol. 2002, 185, 172-179. [CrossRef]

127. Muzio, G.; Maggiora, M.; Oraldi, M.; Trombetta, A.; Canuto, R.A. PPARalpha and PP2A Are Involved in the Proapoptotic Effect of Conjugated Linoleic Acid on Human Hepatoma Cell Line SK-HEP-1. Int. J. Cancer 2007, 121, 2395-2401. [CrossRef]

128. You, B.-J.; Hour, M.-J.; Chen, L.-Y.; Luo, S.-C.; Hsu, P.-H.; Lee, H.-Z. Fenofibrate Induces Human Hepatoma Hep3B Cells Apoptosis and Necroptosis through Inhibition of Thioesterase Domain of Fatty Acid Synthase. Sci. Rep. 2019, 9, 3306. [CrossRef]

129. Girroir, E.E.; Hollingshead, H.E.; He, P.; Zhu, B.; Perdew, G.H.; Peters, J.M. Quantitative Expression Patterns of Peroxisome Proliferator-Activated Receptor- $\beta / \delta(\operatorname{PPAR} \beta / \delta)$ Protein in Mice. Biochem. Biophys. Res. Commun. 2008, 371, 456-461. [CrossRef] [PubMed]

130. Mandard, S.; Patsouris, D. Nuclear Control of the Inflammatory Response in Mammals by Peroxisome Proliferator-Activated Receptors. Available online: https:/ / www.hindawi.com/journals/ppar/2013/613864/ (accessed on 3 March 2021).

131. Escher, P.; Braissant, O.; Basu-Modak, S.; Michalik, L.; Wahli, W.; Desvergne, B. Rat PPARs: Quantitative Analysis in Adult Rat Tissues and Regulation in Fasting and Refeeding. Endocrinology 2001, 142, 4195-4202. [CrossRef]

132. Luquet, S.; Lopez-Soriano, J.; Holst, D.; Fredenrich, A.; Melki, J.; Rassoulzadegan, M.; Grimaldi, P.A. Peroxisome ProliferatorActivated Receptor Delta Controls Muscle Development and Oxidative Capability. FASEB J. Off. Publ. Fed. Am. Soc. Exp. Biol. 2003, 17, 2299-2301. [CrossRef] 
133. Gan, Z.; Burkart-Hartman, E.M.; Han, D.-H.; Finck, B.; Leone, T.C.; Smith, E.Y.; Ayala, J.E.; Holloszy, J.; Kelly, D.P. The Nuclear Receptor PPAR $\beta / \delta$ Programs Muscle Glucose Metabolism in Cooperation with AMPK and MEF2. Genes Dev. 2011, 25, $2619-2630$. [CrossRef]

134. Tanaka, T.; Yamamoto, J.; Iwasaki, S.; Asaba, H.; Hamura, H.; Ikeda, Y.; Watanabe, M.; Magoori, K.; Ioka, R.X.; Tachibana, K.; et al. Activation of Peroxisome Proliferator-Activated Receptor Delta Induces Fatty Acid Beta-Oxidation in Skeletal Muscle and Attenuates Metabolic Syndrome. Proc. Natl. Acad. Sci. USA 2003, 100, 15924-15929. [CrossRef]

135. Palomer, X.; Barroso, E.; Pizarro-Delgado, J.; Peña, L.; Botteri, G.; Zarei, M.; Aguilar, D.; Montori-Grau, M.; Vázquez-Carrera, M. PPAR $\beta / \delta$ : A Key Therapeutic Target in Metabolic Disorders. Int. J. Mol. Sci. 2018, 19, 913. [CrossRef] [PubMed]

136. Mackenzie, L.S.; Lione, L. Harnessing the Benefits of PPAR $\beta / \delta$ Agonists. Life Sci. 2013, 93, 963-967. [CrossRef] [PubMed]

137. Olson, E.J.; Pearce, G.L.; Jones, N.P.; Sprecher, D.L. Lipid Effects of Peroxisome Proliferator-Activated Receptor- $\delta$ Agonist GW501516 in Subjects with Low High-Density Lipoprotein Cholesterol: Characteristics of Metabolic Syndrome. Arterioscler. Thromb. Vasc. Biol. 2012, 32, 2289-2294. [CrossRef] [PubMed]

138. Lee, M.Y.; Choi, R.; Kim, H.M.; Cho, E.J.; Kim, B.H.; Choi, Y.S.; Naowaboot, J.; Lee, E.Y.; Yang, Y.C.; Shin, J.Y.; et al. Peroxisome Proliferator-Activated Receptor $\delta$ Agonist Attenuates Hepatic Steatosis by Anti-Inflammatory Mechanism. Exp. Mol. Med. 2012, 44, 578-585. [CrossRef]

139. Nagasawa, T.; Inada, Y.; Nakano, S.; Tamura, T.; Takahashi, T.; Maruyama, K.; Yamazaki, Y.; Kuroda, J.; Shibata, N. Effects of Bezafibrate, PPAR Pan-Agonist, and GW501516, PPARdelta Agonist, on Development of Steatohepatitis in Mice Fed a Methionineand Choline-Deficient Diet. Eur. J. Pharmacol. 2006, 536, 182-191. [CrossRef]

140. Lee, C.-H.; Olson, P.; Hevener, A.; Mehl, I.; Chong, L.-W.; Olefsky, J.M.; Gonzalez, F.J.; Ham, J.; Kang, H.; Peters, J.M.; et al. PPARdelta Regulates Glucose Metabolism and Insulin Sensitivity. Proc. Natl. Acad. Sci. USA 2006, 103, 3444-3449. [CrossRef]

141. Tong, L.; Wang, L.; Yao, S.; Jin, L.; Yang, J.; Zhang, Y.; Ning, G.; Zhang, Z. PPAR $\delta$ Attenuates Hepatic Steatosis through Autophagy-Mediated Fatty Acid Oxidation. Cell Death Dis. 2019, 10, 1-14. [CrossRef]

142. Bays, H.E.; Schwartz, S.; Littlejohn, T.; Kerzner, B.; Krauss, R.M.; Karpf, D.B.; Choi, Y.-J.; Wang, X.; Naim, S.; Roberts, B.K. MBX8025, a Novel Peroxisome Proliferator Receptor-Delta Agonist: Lipid and Other Metabolic Effects in Dyslipidemic Overweight Patients Treated with and without Atorvastatin. J. Clin. Endocrinol. Metab. 2011, 96, 2889-2897. [CrossRef]

143. Risérus, U.; Sprecher, D.; Johnson, T.; Olson, E.; Hirschberg, S.; Liu, A.; Fang, Z.; Hegde, P.; Richards, D.; Sarov-Blat, L.; et al. Activation of Peroxisome Proliferator-Activated Receptor (PPAR)Delta Promotes Reversal of Multiple Metabolic Abnormalities, Reduces Oxidative Stress, and Increases Fatty Acid Oxidation in Moderately Obese Men. Diabetes 2008, 57, 332-339. [CrossRef] [PubMed]

144. Gupta, R.A.; Wang, D.; Katkuri, S.; Wang, H.; Dey, S.K.; DuBois, R.N. Activation of Nuclear Hormone Receptor Peroxisome Proliferator-Activated Receptor-Delta Accelerates Intestinal Adenoma Growth. Nat. Med. 2004, 10, 245-247. [CrossRef] [PubMed]

145. Peters, J.M.; Gonzalez, F.J.; Müller, R. Establishing the Role of PPAR $\beta$ / $\delta$ in Carcinogenesis. Trends Endocrinol. Metab. 2015, 26, 595-607. [CrossRef] [PubMed]

146. Barroso, E.; Rodríguez-Calvo, R.; Serrano-Marco, L.; Astudillo, A.M.; Balsinde, J.; Palomer, X.; Vázquez-Carrera, M. The PPAR $\beta / \delta$ Activator GW501516 Prevents the down-Regulation of AMPK Caused by a High-Fat Diet in Liver and Amplifies the PGC-1 $\alpha$-Lipin 1-PPAR $\alpha$ Pathway Leading to Increased Fatty Acid Oxidation. Endocrinology 2011, 152, 1848-1859. [CrossRef]

147. Cariou, B.; Zaïr, Y.; Staels, B.; Bruckert, E. Effects of the New Dual PPAR $\alpha / \delta$ Agonist GFT505 on Lipid and Glucose Homeostasis in Abdominally Obese Patients With Combined Dyslipidemia or Impaired Glucose Metabolism. Diabetes Care 2011, 34, 2008-2014. [CrossRef]

148. Cariou, B.; Hanf, R.; Lambert-Porcheron, S.; Zaïr, Y.; Sauvinet, V.; Noël, B.; Flet, L.; Vidal, H.; Staels, B.; Laville, M. Dual Peroxisome Proliferator-Activated Receptor $\alpha / \delta$ Agonist GFT505 Improves Hepatic and Peripheral Insulin Sensitivity in Abdominally Obese Subjects. Diabetes Care 2013, 36, 2923-2930. [CrossRef] [PubMed]

149. Staels, B.; Rubenstrunk, A.; Noel, B.; Rigou, G.; Delataille, P.; Millatt, L.J.; Baron, M.; Lucas, A.; Tailleux, A.; Hum, D.W.; et al. Hepatoprotective Effects of the Dual Peroxisome Proliferator-Activated Receptor Alpha/Delta Agonist, GFT505, in Rodent Models of Nonalcoholic Fatty Liver Disease/Nonalcoholic Steatohepatitis. Hepatol. Baltim. Md 2013, 58, 1941-1952. [CrossRef]

150. Ratziu, V.; Harrison, S.A.; Francque, S.; Bedossa, P.; Lehert, P.; Serfaty, L.; Romero-Gomez, M.; Boursier, J.; Abdelmalek, M.; Caldwell, S.; et al. Elafibranor, an Agonist of the Peroxisome Proliferator-Activated Receptor- $\alpha$ and $-\delta$, Induces Resolution of Nonalcoholic Steatohepatitis Without Fibrosis Worsening. Gastroenterology 2016, 150, 1147-1159.e5. [CrossRef]

151. Liu, L.; Liu, C.; Zhao, M.; Zhang, Q.; Lu, Y.; Liu, P.; Yang, H.; Yang, J.; Chen, X.; Yao, Y. The Pharmacodynamic and Differential Gene Expression Analysis of PPAR $\alpha / \delta$ Agonist GFT505 in CDAHFD-Induced NASH Model. PLoS ONE 2020, 15, e0243911. [CrossRef]

152. Tølbøl, K.S.; Kristiansen, M.N.; Hansen, H.H.; Veidal, S.S.; Rigbolt, K.T.; Gillum, M.P.; Jelsing, J.; Vrang, N.; Feigh, M. Metabolic and Hepatic Effects of Liraglutide, Obeticholic Acid and Elafibranor in Diet-Induced Obese Mouse Models of Biopsy-Confirmed Nonalcoholic Steatohepatitis. World J. Gastroenterol. 2018, 24, 179-194. [CrossRef]

153. Shen, B.; Li, A.; Wan, Y.-J.Y.; Shen, G.; Zhu, J.; Nie, Y. Lack of PPAR $\beta$ / $\delta$-Inactivated SGK-1 Is Implicated in Liver Carcinogenesis. BioMed Res. Int. 2020, 2020, 9563851. [CrossRef]

154. Balandaram, G.; Kramer, L.R.; Kang, B.-H.; Murray, I.A.; Perdew, G.H.; Gonzalez, F.J.; Peters, J.M. Ligand Activation of Peroxisome Proliferator-Activated Receptor- $\beta$ / $\delta$ Suppresses Liver Tumorigenesis in Hepatitis B Transgenic Mice. Toxicology 2016, 363-364, 1-9. [CrossRef] 
155. Chávez-Talavera, O.; Tailleux, A.; Lefebvre, P.; Staels, B. Bile Acid Control of Metabolism and Inflammation in Obesity, Type 2 Diabetes, Dyslipidemia, and Nonalcoholic Fatty Liver Disease. Gastroenterology 2017, 152, 1679-1694.e3. [CrossRef] [PubMed]

156. Grzych, G.; Chávez-Talavera, O.; Descat, A.; Thuillier, D.; Verrijken, A.; Kouach, M.; Legry, V.; Verkindt, H.; Raverdy, V.; Legendre, B.; et al. NASH-Related Increases in Plasma Bile Acid Levels Depend on Insulin Resistance. JHEP Rep. 2021, 3, 100222. [CrossRef]

157. Mouzaki, M.; Wang, A.Y.; Bandsma, R.; Comelli, E.M.; Arendt, B.M.; Zhang, L.; Fung, S.; Fischer, S.E.; McGilvray, I.G.; Allard, J.P. Bile Acids and Dysbiosis in Non-Alcoholic Fatty Liver Disease. PLoS ONE 2016, 11, e0151829. [CrossRef]

158. Arab, J.P.; Karpen, S.J.; Dawson, P.A.; Arrese, M.; Trauner, M. Bile Acids and Nonalcoholic Fatty Liver Disease: Molecular Insights and Therapeutic Perspectives. Hepatology 2017, 65, 350-362. [CrossRef] [PubMed]

159. Jiao, N.; Baker, S.S.; Chapa-Rodriguez, A.; Liu, W.; Nugent, C.A.; Tsompana, M.; Mastrandrea, L.; Buck, M.J.; Baker, R.D.; Genco, R.J.; et al. Suppressed Hepatic Bile Acid Signalling despite Elevated Production of Primary and Secondary Bile Acids in NAFLD. Gut 2018, 67, 1881-1891. [CrossRef]

160. Gottlieb, A.; Canbay, A. Why Bile Acids Are So Important in Non-Alcoholic Fatty Liver Disease (NAFLD) Progression. Cells 2019, 8, 1358. [CrossRef] [PubMed]

161. Okushin, K.; Tsutsumi, T.; Enooku, K.; Fujinaga, H.; Kado, A.; Shibahara, J.; Fukayama, M.; Moriya, K.; Yotsuyanagi, H.; Koike, K. The Intrahepatic Expression Levels of Bile Acid Transporters Are Inversely Correlated with the Histological Progression of Nonalcoholic Fatty Liver Disease. J. Gastroenterol. 2016, 51, 808-818. [CrossRef]

162. Wang, H.; Chen, J.; Hollister, K.; Sowers, L.C.; Forman, B.M. Endogenous Bile Acids Are Ligands for the Nuclear Receptor FXR/BAR. Mol. Cell 1999, 3, 543-553. [CrossRef]

163. Chiang, J.Y.L. Bile Acid Metabolism and Signaling in Liver Disease and Therapy. Liver Res. 2017, 1, 3-9. [CrossRef] [PubMed]

164. Zhang, Y.; Lee, F.Y.; Barrera, G.; Lee, H.; Vales, C.; Gonzalez, F.J.; Willson, T.M.; Edwards, P.A. Activation of the Nuclear Receptor FXR Improves Hyperglycemia and Hyperlipidemia in Diabetic Mice. Proc. Natl. Acad. Sci. USA 2006, 103, 1006-1011. [CrossRef] [PubMed]

165. Zhang, S.; Wang, J.; Liu, Q.; Harnish, D.C. Farnesoid X Receptor Agonist WAY-362450 Attenuates Liver Inflammation and Fibrosis in Murine Model of Non-Alcoholic Steatohepatitis. J. Hepatol. 2009, 51, 380-388. [CrossRef]

166. Cariou, B.; van Harmelen, K.; Duran-Sandoval, D.; van Dijk, T.H.; Grefhorst, A.; Abdelkarim, M.; Caron, S.; Torpier, G.; Fruchart, J.-C.; Gonzalez, F.J.; et al. The Farnesoid X Receptor Modulates Adiposity and Peripheral Insulin Sensitivity in Mice. J. Biol. Chem. 2006, 281, 11039-11049. [CrossRef]

167. Wang, X.; Fu, X.; Van Ness, C.; Meng, Z.; Ma, X.; Huang, W. Bile Acid Receptors and Liver Cancer. Curr. Pathobiol. Rep. 2013, 1, 29-35. [CrossRef]

168. Wang, Y.-D.; Chen, W.-D.; Wang, M.; Yu, D.; Forman, B.M.; Huang, W. Farnesoid X Receptor Antagonizes Nuclear Factor KB in Hepatic Inflammatory Response. Hepatology 2008, 48, 1632-1643. [CrossRef] [PubMed]

169. Kim, I.; Morimura, K.; Shah, Y.; Yang, Q.; Ward, J.M.; Gonzalez, F.J. Spontaneous Hepatocarcinogenesis in Farnesoid X ReceptorNull Mice. Carcinogenesis 2007, 28, 940-946. [CrossRef]

170. Zhang, Y.; Ge, X.; Heemstra, L.A.; Chen, W.-D.; Xu, J.; Smith, J.L.; Ma, H.; Kasim, N.; Edwards, P.A.; Novak, C.M. Loss of FXR Protects against Diet-Induced Obesity and Accelerates Liver Carcinogenesis in Ob/Ob Mice. Mol. Endocrinol. Baltim. Md 2012, 26, 272-280. [CrossRef] [PubMed]

171. Wolfe, A.; Thomas, A.; Edwards, G.; Jaseja, R.; Guo, G.L.; Apte, U. Increased Activation of the Wnt/ $\beta$-Catenin Pathway in Spontaneous Hepatocellular Carcinoma Observed in Farnesoid X Receptor Knockout Mice. J. Pharmacol. Exp. Ther. 2011, 338, 12-21. [CrossRef]

172. Guo, F.; Xu, Z.; Zhang, Y.; Jiang, P.; Huang, G.; Chen, S.; Lyu, X.; Zheng, P.; Zhao, X.; Zeng, Y.; et al. FXR Induces SOCS3 and Suppresses Hepatocellular Carcinoma. Oncotarget 2015, 6, 34606-34616. [CrossRef]

173. Liu, N.; Meng, Z.; Lou, G.; Zhou, W.; Wang, X.; Zhang, Y.; Zhang, L.; Liu, X.; Yen, Y.; Lai, L.; et al. Hepatocarcinogenesis in FXR-/Mice Mimics Human HCC Progression That Operates through HNF1 $\alpha$ Regulation of FXR Expression. Mol. Endocrinol. Baltim. Md 2012, 26, 775-785. [CrossRef]

174. Anfuso, B.; Tiribelli, C.; Adorini, L.; Rosso, N. Obeticholic Acid and INT-767 Modulate Collagen Deposition in a NASH in Vitro Model. Sci. Rep. 2020, 10, 1699. [CrossRef]

175. Cipriani, S.; Mencarelli, A.; Palladino, G.; Fiorucci, S. FXR Activation Reverses Insulin Resistance and Lipid Abnormalities and Protects against Liver Steatosis in Zucker (Fa/Fa) Obese Rats. J. Lipid Res. 2010, 51, 771-784. [CrossRef] [PubMed]

176. Roth, J.D.; Veidal, S.S.; Fensholdt, L.K.D.; Rigbolt, K.T.G.; Papazyan, R.; Nielsen, J.C.; Feigh, M.; Vrang, N.; Young, M.; Jelsing, J.; et al. Combined Obeticholic Acid and Elafibranor Treatment Promotes Additive Liver Histological Improvements in a Diet-Induced Ob/Ob Mouse Model of Biopsy-Confirmed NASH. Sci. Rep. 2019, 9, 9046. [CrossRef]

177. Goto, T.; Itoh, M.; Suganami, T.; Kanai, S.; Shirakawa, I.; Sakai, T.; Asakawa, M.; Yoneyama, T.; Kai, T.; Ogawa, Y. Obeticholic Acid Protects against Hepatocyte Death and Liver Fibrosis in a Murine Model of Nonalcoholic Steatohepatitis. Sci. Rep. 2018, 8, 8157. [CrossRef] [PubMed]

178. Mudaliar, S.; Henry, R.R.; Sanyal, A.J.; Morrow, L.; Marschall, H.-U.; Kipnes, M.; Adorini, L.; Sciacca, C.I.; Clopton, P.; Castelloe, E.; et al. Efficacy and Safety of the Farnesoid X Receptor Agonist Obeticholic Acid in Patients with Type 2 Diabetes and Nonalcoholic Fatty Liver Disease. Gastroenterology 2013, 145, 574-582.e1. [CrossRef] 
179. Neuschwander-Tetri, B.A.; Loomba, R.; Sanyal, A.J.; Lavine, J.E.; Van Natta, M.L.; Abdelmalek, M.F.; Chalasani, N.; Dasarathy, S.; Diehl, A.M.; Hameed, B.; et al. Farnesoid X Nuclear Receptor Ligand Obeticholic Acid for Non-Cirrhotic, Non-Alcoholic Steatohepatitis (FLINT): A Multicentre, Randomised, Placebo-Controlled Trial. Lancet Lond. Engl. 2015, 385, 956-965. [CrossRef]

180. Younossi, Z.M.; Ratziu, V.; Loomba, R.; Rinella, M.; Anstee, Q.M.; Goodman, Z.; Bedossa, P.; Geier, A.; Beckebaum, S.; Newsome, P.N.; et al. Obeticholic Acid for the Treatment of Non-Alcoholic Steatohepatitis: Interim Analysis from a Multicentre, Randomised, Placebo-Controlled Phase 3 Trial. Lancet Lond. Engl. 2019, 394, 2184-2196. [CrossRef]

181. Al-Dury, S.; Wahlström, A.; Panzitt, K.; Thorell, A.; Ståhlman, M.; Trauner, M.; Fickert, P.; Bäckhed, F.; Fändriks, L.; Wagner, M.; et al. Obeticholic Acid May Increase the Risk of Gallstone Formation in Susceptible Patients. J. Hepatol. 2019, 71, 986-991. [CrossRef]

182. Attia, Y.M.; Tawfiq, R.A.; Ali, A.A.; Elmazar, M.M. The FXR Agonist, Obeticholic Acid, Suppresses HCC Proliferation \& Metastasis: Role of IL-6/STAT3 Signalling Pathway. Sci. Rep. 2017, 7, 12502. [CrossRef]

183. Zhang, R.; Ray, J.W.; Jain, M.K.; Han, S. Ileectomy-Induced Bile Overaccumulation in Mouse Intestine. J. Vis. Exp. JoVE 2017. [CrossRef]

184. Van de Peppel, I.P.; Verkade, H.J.; Jonker, J.W. Metabolic Consequences of Ileal Interruption of the Enterohepatic Circulation of Bile Acids. Am. J. Physiol. Gastrointest. Liver Physiol. 2020, 319, G619-G625. [CrossRef]

185. Lee, Y.-S.; Jun, H.-S. Anti-Diabetic Actions of Glucagon-like Peptide-1 on Pancreatic Beta-Cells. Metabolism 2014, 63, 9-19. [CrossRef] [PubMed]

186. Abraham, E.J.; Leech, C.A.; Lin, J.C.; Zulewski, H.; Habener, J.F. Insulinotropic Hormone Glucagon-like Peptide-1 Differentiation of Human Pancreatic Islet-Derived Progenitor Cells into Insulin-Producing Cells. Endocrinology 2002, 143, 3152-3161. [CrossRef]

187. Gupta, N.A.; Mells, J.; Dunham, R.M.; Grakoui, A.; Handy, J.; Saxena, N.K.; Anania, F.A. Glucagon-like Peptide-1 Receptor (GLP-1R) Is Present on Human Hepatocytes and Has a Direct Role in Decreasing Hepatic Steatosis in Vitro by Modulating Elements of the Insulin Signaling Pathway. Hepatol. Baltim. Md 2010, 51, 1584-1592. [CrossRef]

188. Samson, S.L.; Bajaj, M. Potential of Incretin-Based Therapies for Non-Alcoholic Fatty Liver Disease. J. Diabetes Complicat. 2013, 27, 401-406. [CrossRef] [PubMed]

189. Petit, J.-M.; Vergès, B. GLP-1 Receptor Agonists in NAFLD. Diabetes Metab. 2017, 43, 2S28-2S33. [CrossRef]

190. Svegliati-Baroni, G.; Saccomanno, S.; Rychlicki, C.; Agostinelli, L.; Minicis, S.D.; Candelaresi, C.; Faraci, G.; Pacetti, D.; Vivarelli, M.; Nicolini, D.; et al. Glucagon-like Peptide-1 Receptor Activation Stimulates Hepatic Lipid Oxidation and Restores Hepatic Signalling Alteration Induced by a High-Fat Diet in Nonalcoholic Steatohepatitis. Liver Int. 2011, 31, 1285-1297. [CrossRef] [PubMed]

191. Sharma, S.; Mells, J.E.; Fu, P.P.; Saxena, N.K.; Anania, F.A. GLP-1 Analogs Reduce Hepatocyte Steatosis and Improve Survival by Enhancing the Unfolded Protein Response and Promoting Macroautophagy. PLoS ONE 2011, 6, e25269. [CrossRef] [PubMed]

192. Krause, G.C.; Lima, K.G.; Levorse, V.; Haute, G.V.; Gassen, R.B.; Garcia, M.C.; Pedrazza, L.; Donadio, M.V.F.; Luft, C.; de Oliveira, J.R. Exenatide Induces Autophagy and Prevents the Cell Regrowth in HepG2 Cells. EXCLI J. 2019, 18, 540-548. [CrossRef]

193. Krause, G.C.; Lima, K.G.; Dias, H.B.; da Silva, E.F.G.; Haute, G.V.; Basso, B.S.; Gassen, R.B.; Marczak, E.S.; Nunes, R.S.B.; de Oliveira, J.R. Liraglutide, a Glucagon-like Peptide-1 Analog, Induce Autophagy and Senescence in HepG2 Cells. Eur. J. Pharmacol. 2017, 809, 32-41. [CrossRef]

194. Lu, X.; Xu, C.; Dong, J.; Zuo, S.; Zhang, H.; Jiang, C.; Wu, J.; Wei, J. Liraglutide Activates Nature Killer Cell-Mediated Antitumor Responses by Inhibiting IL-6/STAT3 Signaling in Hepatocellular Carcinoma. Transl. Oncol. 2021, 14, 100872. [CrossRef]

195. Tong, W.; Ju, L.; Qiu, M.; Xie, Q.; Chen, Y.; Shen, W.; Sun, W.; Wang, W.; Tian, J. Liraglutide Ameliorates Non-Alcoholic Fatty Liver Disease by Enhancing Mitochondrial Architecture and Promoting Autophagy through the SIRT1/SIRT3-FOXO3a Pathway. Hepatol. Res. Off. J. Jpn. Soc. Hepatol. 2016, 46, 933-943. [CrossRef]

196. Trevaskis, J.L.; Griffin, P.S.; Wittmer, C.; Neuschwander-Tetri, B.A.; Brunt, E.M.; Dolman, C.S.; Erickson, M.R.; Napora, J.; Parkes, D.G.; Roth, J.D. Glucagon-like Peptide-1 Receptor Agonism Improves Metabolic, Biochemical, and Histopathological Indices of Nonalcoholic Steatohepatitis in Mice. Am. J. Physiol. Gastrointest. Liver Physiol. 2012, 302, G762-G772. [CrossRef] [PubMed]

197. Ding, X.; Saxena, N.K.; Lin, S.; Gupta, N.A.; Gupta, N.; Anania, F.A. Exendin-4, a Glucagon-like Protein-1 (GLP-1) Receptor Agonist, Reverses Hepatic Steatosis in Ob/Ob Mice. Hepatol. Baltim. Md 2006, 43, 173-181. [CrossRef]

198. Lv, X.; Dong, Y.; Hu, L.; Lu, F.; Zhou, C.; Qin, S. Glucagon-like Peptide-1 Receptor Agonists (GLP-1 RAs) for the Management of Nonalcoholic Fatty Liver Disease (NAFLD): A Systematic Review. Endocrinol. Diabetes Metab. 2020, 3, e00163. [CrossRef]

199. Kojima, M.; Takahashi, H.; Kuwashiro, T.; Tanaka, K.; Mori, H.; Ozaki, I.; Kitajima, Y.; Matsuda, Y.; Ashida, K.; Eguchi, Y.; et al. Glucagon-Like Peptide-1 Receptor Agonist Prevented the Progression of Hepatocellular Carcinoma in a Mouse Model of Nonalcoholic Steatohepatitis. Int. J. Mol. Sci. 2020, 21, 5722. [CrossRef] [PubMed]

200. Kawakubo, M.; Tanaka, M.; Ochi, K.; Watanabe, A.; Saka-Tanaka, M.; Kanamori, Y.; Yoshioka, N.; Yamashita, S.; Goto, M.; Itoh, M.; et al. Dipeptidyl Peptidase-4 Inhibition Prevents Nonalcoholic Steatohepatitis-Associated Liver Fibrosis and Tumor Development in Mice Independently of Its Anti-Diabetic Effects. Sci. Rep. 2020, 10, 983. [CrossRef]

201. Calvisi, D.F.; Wang, C.; Ho, C.; Ladu, S.; Lee, S.A.; Mattu, S.; Destefanis, G.; Delogu, S.; Zimmermann, A.; Ericsson, J.; et al. Increased Lipogenesis, Induced by AKT-MTORC1-RPS6 Signaling, Promotes Development of Human Hepatocellular Carcinoma. Gastroenterology 2011, 140, 1071-1083. [CrossRef] 
202. Nelson, M.E.; Lahiri, S.; Chow, J.D.Y.; Byrne, F.L.; Hargett, S.R.; Breen, D.S.; Olzomer, E.M.; Wu, L.E.; Cooney, G.J.; Turner, N.; et al. Inhibition of Hepatic Lipogenesis Enhances Liver Tumorigenesis by Increasing Antioxidant Defence and Promoting Cell Survival. Nat. Commun. 2017, 8, 14689. [CrossRef] [PubMed]

203. Jiang, X.; Tan, H.-Y.; Teng, S.; Chan, Y.-T.; Wang, D.; Wang, N. The Role of AMP-Activated Protein Kinase as a Potential Target of Treatment of Hepatocellular Carcinoma. Cancers 2019, 11, 647. [CrossRef]

204. Ferretti, A.C.; Hidalgo, F.; Tonucci, F.M.; Almada, E.; Pariani, A.; Larocca, M.C.; Favre, C. Metformin and Glucose Starvation Decrease the Migratory Ability of Hepatocellular Carcinoma Cells: Targeting AMPK Activation to Control Migration. Sci. Rep. 2019, 9, 2815. [CrossRef]

205. Abu-Elheiga, L.; Brinkley, W.R.; Zhong, L.; Chirala, S.S.; Woldegiorgis, G.; Wakil, S.J. The Subcellular Localization of Acetyl-CoA Carboxylase 2. Proc. Natl. Acad. Sci. USA 2000, 97, 1444-1449. [CrossRef]

206. Harriman, G.; Greenwood, J.; Bhat, S.; Huang, X.; Wang, R.; Paul, D.; Tong, L.; Saha, A.K.; Westlin, W.F.; Kapeller, R.; et al. AcetylCoA Carboxylase Inhibition by ND-630 Reduces Hepatic Steatosis, Improves Insulin Sensitivity, and Modulates Dyslipidemia in Rats. Proc. Natl. Acad. Sci. USA 2016, 113, E1796-E1805. [CrossRef]

207. Goedeke, L.; Bates, J.; Vatner, D.F.; Perry, R.J.; Wang, T.; Ramirez, R.; Li, L.; Ellis, M.W.; Zhang, D.; Wong, K.E.; et al. Acetyl-CoA Carboxylase Inhibition Reverses NAFLD and Hepatic Insulin Resistance but Promotes Hypertriglyceridemia in Rodents. Hepatol. Baltim. Md 2018, 68, 2197-2211. [CrossRef] [PubMed]

208. Kim, C.-W.; Addy, C.; Kusunoki, J.; Anderson, N.N.; Deja, S.; Fu, X.; Burgess, S.C.; Li, C.; Ruddy, M.; Chakravarthy, M.; et al. Acetyl CoA Carboxylase Inhibition Reduces Hepatic Steatosis but Elevates Plasma Triglycerides in Mice and Humans: A Bedside to Bench Investigation. Cell Metab. 2017, 26, 394-406.e6. [CrossRef] [PubMed]

209. Loomba, R.; Kayali, Z.; Noureddin, M.; Ruane, P.; Lawitz, E.J.; Bennett, M.; Wang, L.; Harting, E.; Tarrant, J.M.; McColgan, B.J.; et al. GS-0976 Reduces Hepatic Steatosis and Fibrosis Markers in Patients With Nonalcoholic Fatty Liver Disease. Gastroenterology 2018, 155, 1463-1473.e6. [CrossRef] [PubMed]

210. Lawitz, E.J.; Coste, A.; Poordad, F.; Alkhouri, N.; Loo, N.; McColgan, B.J.; Tarrant, J.M.; Nguyen, T.; Han, L.; Chung, C.; et al. Acetyl-CoA Carboxylase Inhibitor GS-0976 for 12 Weeks Reduces Hepatic De Novo Lipogenesis and Steatosis in Patients With Nonalcoholic Steatohepatitis. Clin. Gastroenterol. Hepatol. Off. Clin. Pract. J. Am. Gastroenterol. Assoc. 2018, 16, 1983-1991.e3. [CrossRef]

211. Stiede, K.; Miao, W.; Blanchette, H.S.; Beysen, C.; Harriman, G.; Harwood, H.J.; Kelley, H.; Kapeller, R.; Schmalbach, T.; Westlin, W.F. Acetyl-Coenzyme A Carboxylase Inhibition Reduces de Novo Lipogenesis in Overweight Male Subjects: A Randomized, Double-Blind, Crossover Study. Hepatol. Baltim. Md 2017, 66, 324-334. [CrossRef]

212. Lally, J.S.V.; Ghoshal, S.; DePeralta, D.K.; Moaven, O.; Wei, L.; Masia, R.; Erstad, D.J.; Fujiwara, N.; Leong, V.; Houde, V.P.; et al. Inhibition of Acetyl-CoA Carboxylase (ACC) by Phosphorylation or by the Liver-Specific Inhibitor, ND-654, Suppresses Lipogenesis and Hepatocellular Carcinoma. Cell Metab. 2019, 29, 174-182.e5. [CrossRef] [PubMed]

213. Istvan, E.S.; Deisenhofer, J. Structural Mechanism for Statin Inhibition of HMG-CoA Reductase. Science 2001, $292,1160-1164$. [CrossRef] [PubMed]

214. Sigler, M.A.; Congdon, L.; Edwards, K.L. An Evidence-Based Review of Statin Use in Patients With Nonalcoholic Fatty Liver Disease. Clin. Med. Insights Gastroenterol. 2018, 11. [CrossRef] [PubMed]

215. Athyros, V.G.; Boutari, C.; Stavropoulos, K.; Anagnostis, P.; Imprialos, K.P.; Doumas, M.; Karagiannis, A. Statins: An UnderAppreciated Asset for the Prevention and the Treatment of NAFLD or NASH and the Related Cardiovascular Risk. Curr. Vasc. Pharmacol. 2018, 16, 246-253. [CrossRef]

216. Doumas, M.; Imprialos, K.; Dimakopoulou, A.; Stavropoulos, K.; Binas, A.; Athyros, V.G. The Role of Statins in the Management of Nonalcoholic Fatty Liver Disease. Curr. Pharm. Des. 2018, 24, 4587-4592. [CrossRef]

217. Singh, S.; Singh, P.P.; Singh, A.G.; Murad, M.H.; Sanchez, W. Statins Are Associated with a Reduced Risk of Hepatocellular Cancer: A Systematic Review and Meta-Analysis. Gastroenterology 2013, 144, 323-332. [CrossRef]

218. Wong, Y.-J.; Qiu, T.-Y.; Ng, G.-K.; Zheng, Q.; Teo, E.K. Efficacy and Safety of Statin for Hepatocellular Carcinoma Prevention Among Chronic Liver Disease Patients: A Systematic Review and Meta-Analysis. J. Clin. Gastroenterol. 2021. [CrossRef]

219. Goh, M.J.; Sinn, D.H.; Kim, S.; Woo, S.Y.; Cho, H.; Kang, W.; Gwak, G.-Y.; Paik, Y.-H.; Choi, M.S.; Lee, J.H.; et al. Statin Use and the Risk of Hepatocellular Carcinoma in Patients With Chronic Hepatitis B. Hepatol. Baltim. Md 2020, 71, 2023-2032. [CrossRef]

220. Li, X.; Sheng, L.; Liu, L.; Hu, Y.; Chen, Y.; Lou, L. Statin and the Risk of Hepatocellular Carcinoma in Patients with Hepatitis B Virus or Hepatitis C Virus Infection: A Meta-Analysis. BMC Gastroenterol. 2020, 20, 98. [CrossRef] [PubMed]

221. Chang, Y.; Liu, Q.; Zhou, Z.; Ding, Y.; Yang, M.; Xu, W.; Chen, K.; Zhang, Q.; Wang, Z.; Li, H. Can Statin Treatment Reduce the Risk of Hepatocellular Carcinoma? A Systematic Review and Meta-Analysis. Technol. Cancer Res. Treat. 2020, $19,1533033820934881$. [CrossRef]

222. Gu, Y.; Yang, X.; Liang, H.; Li, D. Comprehensive Evaluation of Effects and Safety of Statin on the Progression of Liver Cirrhosis: A Systematic Review and Meta-Analysis. BMC Gastroenterol. 2019, 19, 231. [CrossRef]

223. McGlynn, K.A.; Divine, G.W.; Sahasrabuddhe, V.V.; Engel, L.S.; VanSlooten, A.; Wells, K.; Yood, M.U.; Alford, S.H. Statin Use and Risk of Hepatocellular Carcinoma in a U.S. Population. Cancer Epidemiol. 2014, 38, 523-527. [CrossRef] [PubMed]

224. Lonardo, A.; Loria, P. Potential for Statins in the Chemoprevention and Management of Hepatocellular Carcinoma. J. Gastroenterol. Hepatol. 2012, 27, 1654-1664. [CrossRef] 
225. Shimizu, M.; Yasuda, Y.; Sakai, H.; Kubota, M.; Terakura, D.; Baba, A.; Ohno, T.; Kochi, T.; Tsurumi, H.; Tanaka, T.; et al. Pitavastatin Suppresses Diethylnitrosamine-Induced Liver Preneoplasms in Male C57BL/KsJ-Db/Db Obese Mice. BMC Cancer 2011, 11, 281. [CrossRef]

226. Cao, Z.; Fan-Minogue, H.; Bellovin, D.I.; Yevtodiyenko, A.; Arzeno, J.; Yang, Q.; Gambhir, S.S.; Felsher, D.W. MYC Phosphorylation, Activation, and Tumorigenic Potential in Hepatocellular Carcinoma Are Regulated by HMG-CoA Reductase. Cancer Res. 2011, 71, 2286-2297. [CrossRef]

227. Pastori, D.; Polimeni, L.; Baratta, F.; Pani, A.; Del Ben, M.; Angelico, F. The Efficacy and Safety of Statins for the Treatment of Non-Alcoholic Fatty Liver Disease. Dig. Liver Dis. 2015, 47, 4-11. [CrossRef] [PubMed]

228. Shreiner, A.B.; Kao, J.Y.; Young, V.B. The Gut Microbiome in Health and in Disease. Curr. Opin. Gastroenterol. 2015, $31,69-75$. [CrossRef]

229. Brown, J.M.; Hazen, S.L. The Gut Microbial Endocrine Organ: Bacterially-Derived Signals Driving Cardiometabolic Diseases. Annu. Rev. Med. 2015, 66, 343-359. [CrossRef]

230. Sharpton, S.R.; Ajmera, V.; Loomba, R. Emerging Role of the Gut Microbiome in Nonalcoholic Fatty Liver Disease: From Composition to Function. Clin. Gastroenterol. Hepatol. Off. Clin. Pract. J. Am. Gastroenterol. Assoc. 2019, 17, 296-306. [CrossRef]

231. Schwabe, R.F.; Greten, T.F. Gut Microbiome in HCC-Mechanisms, Diagnosis and Therapy. J. Hepatol. 2020, 72, $230-238$. [CrossRef] [PubMed]

232. Sharpton, S.R.; Schnabl, B.; Knight, R.; Loomba, R. Current Concepts, Opportunities, and Challenges of Gut Microbiome-Based Personalized Medicine in Nonalcoholic Fatty Liver Disease. Cell Metab. 2021, 33, 21-32. [CrossRef] [PubMed]

233. Roberts, A.B.; Gu, X.; Buffa, J.A.; Hurd, A.G.; Wang, Z.; Zhu, W.; Gupta, N.; Skye, S.M.; Cody, D.B.; Levison, B.S.; et al. Development of a Gut Microbe-Targeted Non-Lethal Therapeutic to Inhibit Thrombosis Potential. Nat. Med. 2018, 24, 1407-1417. [CrossRef]

234. Chen, Y.; Liu, Y.; Zhou, R.; Chen, X.; Wang, C.; Tan, X.; Wang, L.; Zheng, R.; Zhang, H.; Ling, W.; et al. Associations of Gut-Flora-Dependent Metabolite Trimethylamine-N-Oxide, Betaine and Choline with Non-Alcoholic Fatty Liver Disease in Adults. Sci. Rep. 2016, 6, 19076. [CrossRef]

235. Anstee, Q.M.; Reeves, H.L.; Kotsiliti, E.; Govaere, O.; Heikenwalder, M. From NASH to HCC: Current Concepts and Future Challenges. Nat. Rev. Gastroenterol. Hepatol. 2019, 16, 411-428. [CrossRef]

236. Schaffer, J.E. Lipotoxicity: Many Roads to Cell Dysfunction and Cell Death: Introduction to a Thematic Review Series. J. Lipid Res. 2016, 57, 1327-1328. [CrossRef]

237. Hirsova, P.; Ibrabim, S.H.; Gores, G.J.; Malhi, H. Lipotoxic Lethal and Sublethal Stress Signaling in Hepatocytes: Relevance to NASH Pathogenesis. J. Lipid Res. 2016, 57, 1758-1770. [CrossRef]

238. Hauck, A.K.; Bernlohr, D.A. Oxidative Stress and Lipotoxicity. J. Lipid Res. 2016, 57, 1976-1986. [CrossRef] [PubMed]

239. Jaishy, B.; Abel, E.D. Lipids, Lysosomes, and Autophagy. J. Lipid Res. 2016, 57, 1619-1635. [CrossRef]

240. Han, J.; Kaufman, R.J. The Role of ER Stress in Lipid Metabolism and Lipotoxicity. J. Lipid Res. 2016, 57, 1329-1338. [CrossRef] [PubMed]

241. Li, S.; Tan, H.-Y.; Wang, N.; Zhang, Z.-J.; Lao, L.; Wong, C.-W.; Feng, Y. The Role of Oxidative Stress and Antioxidants in Liver Diseases. Int. J. Mol. Sci. 2015, 16, 26087-26124. [CrossRef]

242. Rolo, A.P.; Teodoro, J.S.; Palmeira, C.M. Role of Oxidative Stress in the Pathogenesis of Nonalcoholic Steatohepatitis. Free Radic. Biol. Med. 2012, 52, 59-69. [CrossRef] [PubMed]

243. Chen, Z.; Tian, R.; She, Z.; Cai, J.; Li, H. Role of Oxidative Stress in the Pathogenesis of Nonalcoholic Fatty Liver Disease. Free Radic. Biol. Med. 2020, 152, 116-141. [CrossRef]

244. Arroyave-Ospina, J.C.; Wu, Z.; Geng, Y.; Moshage, H. Role of Oxidative Stress in the Pathogenesis of Non-Alcoholic Fatty Liver Disease: Implications for Prevention and Therapy. Antioxidants 2021, 10, 174. [CrossRef]

245. Cholankeril, G.; Patel, R.; Khurana, S.; Satapathy, S.K. Hepatocellular Carcinoma in Non-Alcoholic Steatohepatitis: Current Knowledge and Implications for Management. World J. Hepatol. 2017, 9, 533-543. [CrossRef] [PubMed]

246. Tummala, K.S.; Brandt, M.; Teijeiro, A.; Graña, O.; Schwabe, R.F.; Perna, C.; Djouder, N. Hepatocellular Carcinomas Originate Predominantly from Hepatocytes and Benign Lesions from Hepatic Progenitor Cells. Cell Rep. 2017, 19, 584-600. [CrossRef] [PubMed]

247. Koo, S.-Y.; Park, E.-J.; Lee, C.-W. Immunological Distinctions between Nonalcoholic Steatohepatitis and Hepatocellular Carcinoma. Exp. Mol. Med. 2020, 52, 1209-1219. [CrossRef] [PubMed]

248. Filomeni, G.; De Zio, D.; Cecconi, F. Oxidative Stress and Autophagy: The Clash between Damage and Metabolic Needs. Cell Death Differ. 2015, 22, 377-388. [CrossRef]

249. Yuan, X.; Wang, B.; Yang, L.; Zhang, Y. The Role of ROS-Induced Autophagy in Hepatocellular Carcinoma. Clin. Res. Hepatol. Gastroenterol. 2018, 42, 306-312. [CrossRef]

250. Mizushima, N.; Levine, B. Autophagy in Mammalian Development and Differentiation. Nat. Cell Biol. 2010, 12, 823-830. [CrossRef] [PubMed]

251. Mathiassen, S.G.; De Zio, D.; Cecconi, F. Autophagy and the Cell Cycle: A Complex Landscape. Front. Oncol. 2017, 7, 51. [CrossRef]

252. Maes, H.; Rubio, N.; Garg, A.D.; Agostinis, P. Autophagy: Shaping the Tumor Microenvironment and Therapeutic Response. Trends Mol. Med. 2013, 19, 428-446. [CrossRef] 
253. Mulcahy Levy, J.M.; Thorburn, A. Autophagy in Cancer: Moving from Understanding Mechanism to Improving Therapy Responses in Patients. Cell Death Differ. 2020, 27, 843-857. [CrossRef] [PubMed]

254. Matter, M.S.; Decaens, T.; Andersen, J.B.; Thorgeirsson, S.S. Targeting the MTOR Pathway in Hepatocellular Carcinoma: Current State and Future Trends. J. Hepatol. 2014, 60, 855-865. [CrossRef] [PubMed]

255. Guri, Y.; Colombi, M.; Dazert, E.; Hindupur, S.K.; Roszik, J.; Moes, S.; Jenoe, P.; Heim, M.H.; Riezman, I.; Riezman, H.; et al. MTORC2 Promotes Tumorigenesis via Lipid Synthesis. Cancer Cell 2017, 32, 807-823.e12. [CrossRef]

256. Ferrín, G.; Guerrero, M.; Amado, V.; Rodríguez-Perálvarez, M.; De la Mata, M. Activation of MTOR Signaling Pathway in Hepatocellular Carcinoma. Int. J. Mol. Sci. 2020, 21, 1266. [CrossRef]

257. Zhou, H.-Y.; Huang, S.-L. Current Development of the Second Generation of MTOR Inhibitors as Anticancer Agents. Chin. J. Cancer 2012, 31, 8-18. [CrossRef] [PubMed] 